\title{
The use of emergent technologies to extract added value compounds from grape by-products
}

\author{
M.C. Coelho ${ }^{\mathrm{a}, \mathrm{b}}$, R.N. Pereira ${ }^{\mathrm{b}}$, A.S. Rodrigues ${ }^{\mathrm{c}}$, J.A. Teixeira ${ }^{\mathrm{b}}$, M.E. Pintado ${ }^{\mathrm{a}, *}$ \\ ${ }^{a}$ Universidade Católica Portuguesa, CBQF - Centro de Biotecnologia e Química Fina - Laboratório Associado, Escola Superior de Biotecnologia, Rua Diogo Botelho 1327, \\ 4169-005, Porto, Portugal \\ ${ }^{\mathrm{b}}$ CEB - Centre of Biological Engineering, University of Minho, 4710-057, Braga, Portugal \\ ${ }^{\mathrm{c}}$ Centre for Toxicogenomics and Human Health, Nova Medical School|Faculdade de Ciências Médicas, Universidade Nova de Lisboa, Rua Câmara Pestana, $n^{\circ} 6$ Edifício \\ CEDOC II, Room 2.24, 1150-008, Lisboa, Portugal
}

\section{A R T I C L E I N F O}

\section{Keywords:}

Vitis vinifera

Nutritional value

By-products

Biological activity

Green extraction technologies

Green technologies effects

\begin{abstract}
A B S T R A C T
Background: The current circular economy system-based sustainability and the social lifestyle trends, have led to a developed structure that is restorative or regenerative by purpose and innovation. It substitutes the end-of-life idea of a by-product adding value to it, shifts towards the usage of environmentally friendly solutions, eliminating the harmful chemicals, which impair reuse.

Scope and approach: Considering the wine production, which is one of the most critical agro-industrial sectors worldwide, generating large amounts of by-products with environmental impact, but also with high economic and nutritional potential. This review aims to evaluate the effects of alternative green technologies on the functionality and recovery of bioactive compounds (BCs) from wine by-products.

Key findings and conclusions: These agro-industrial by-products, e.g., skins and pulp remnants, are rich in BCs with health benefits such as supporting the immune system, anti-tumoral, and preventing cardiovascular diseases. Besides, the consumer has increased interest in diet and health, demanding suppliers to consider the reuse of agro-food by-products. Thus, the application of green recovery technologies eliminates the harmful effects comparing to conventional technologies, can be recycled into the food chain as functional additives for different products and applications, guaranteeing the sustainability and reducing the winemaking by-products.
\end{abstract}

\section{Introduction}

According to the United Nations (2017), the global population is about to reach 9.8 billion in 2050, which could not only lead to a decrease in food security but also new food crises. Besides, urbanization, people's lifestyles, such as travel, intensive exploitation of natural resources, and land-use modification, may increase the likelihood of pandemics, such as that currently experienced. Moreover, the current food systems are not sustainable (Galanakis, 2020). Specifically, approximately1.3 billion ton per year of food produced worldwide is wasted (the equivalent to $3300 \mathrm{Mtn}$ of $\mathrm{CO} 2$ emissions per year), with food losses almost $14 \%$ in stages before the retail level, such as agriculture, harvest, catch, and slaughter (FAO, 2019; Galanakis, 2020).

Therefore, it is crucial to think about alternatives that can feed, and at the same time, promote health and support the population' immune system (Galanakis, 2020). Currently, the industrial and agricultural sectors produce large amounts of post-harvest losses and processing by-products and wastes, representing a significant disposal problem for the industry (Gómez-García, Campos, Aguilar, Madureira, \& Pintado, 2020). Those losses and processed materials are, in general, susceptible to the growth of pathogens requiring biological stability and fast treatment (Galanakis, 2012). These by-products usually constitute a promising source of bioactive compounds (BCs) that can be used due to their nutritional properties and biological potential. This permit to obtain benefits from by-products for health promotion and associated to the high value-added of generated ingredients also endorses business (Coman et al., 2019; Galanakis, 2020). Thereby, the collecting of by-products at the source is essential, as well as reducing transportation time. Following the considerations above and the "Universal Recovery Strategy," it is possible to implement affordable, feasible and safe recuperation of high value from food losses and by-products through all-encompassing methodology, see Fig. 1 (Galanakis, 2012). However,

\footnotetext{
* Corresponding author.

E-mail address: mpintado@porto.ucp.pt (M.E. Pintado).
} 


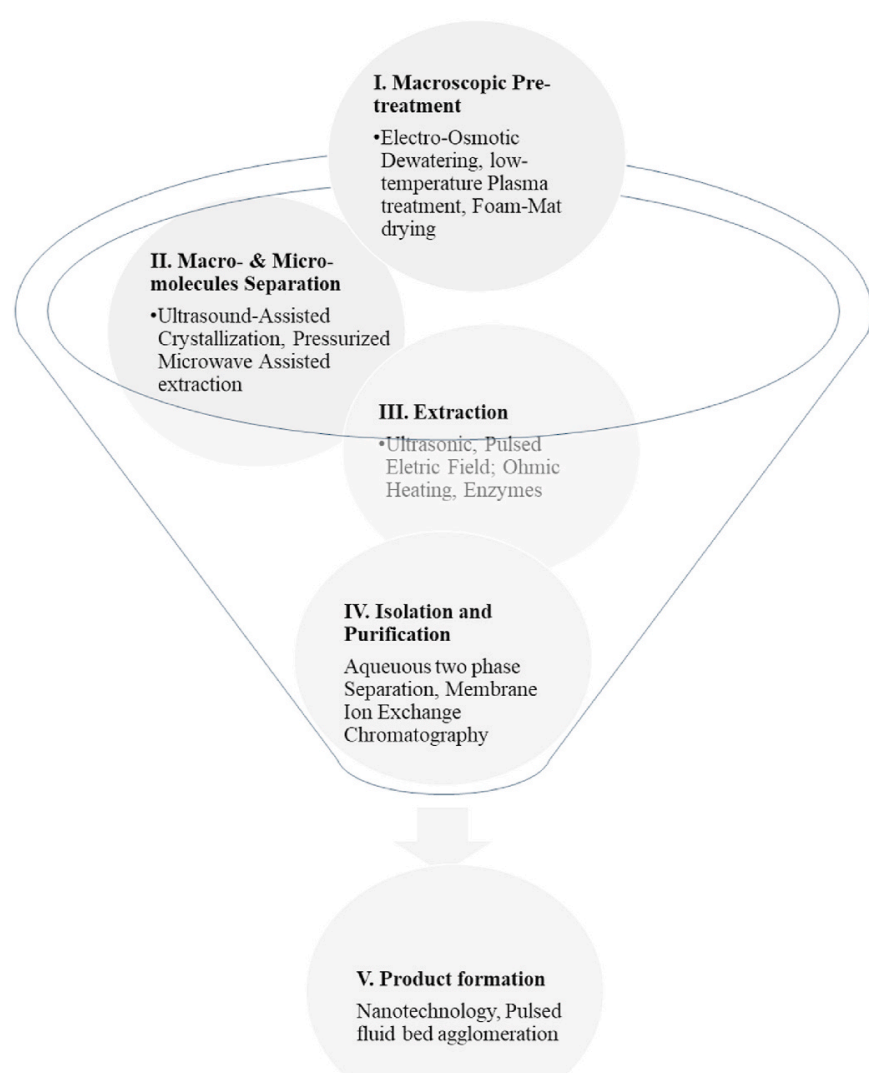

Fig. 1. Recovery stages of high-added-value components with new technologies, adapted from Ganaskis 2012.

many of the current technologies applied to the re-use of by-products have limitations, namely the use of toxic organic solvents that impact on human health, but also on environment (Ananey-Obiri et al., 2018; Galanakis, 2012; Gullón, Gullón, Romaní, Rocchetti, \& Lorenzo, 2020; Zinoviadou et al., 2015). Besides, most of them comprise low efficiency, long extraction times, high energy consumption, and sometimes thermal and hydrolytic compounds degradation (Deng et al., 2015; Sarfarazi, Jafari, Rajabzadeh, \& Galanakis, 2020). In this way, it is imperative to find cleaner and safer alternative techniques and with reduced environmental impact. Currently, the "green extraction" alternatives have been increasingly studied and implemented without the need for "clean-up" processes to recover the compounds that may be safely and immediately consumed or further used in the manufactured of foods (Bursać Kovačević et al., 2018; Deng et al., 2015). Numerous authors have suggested the alternative extraction methods, such as ultrasonic, microwaves, electrical technologies (pulsed electric fields, high electric discharges, and ohmic heating) and mechanical treatment (pressurized hot water extraction and subcritical fluid extraction) (Coelho, Pereira, Rodrigues, Teixeira, \& Pintado, 2019; Deng et al., 2015; Galanakis, 2012, 2015a; Galanakis, Tsatalas, Charalambous, \& Galanakis, 2018; Kalli, Lappa, Bouchagier, Tarantilis, \& Skotti, 2018). These are processes suitable for the improved recovery of valuable compounds since they use green solvents and reduce solvent consumption, and at the same time, they facilitate the plant cell disruption and compounds extraction, minimizing the impact on the BCs (Barba, Zhu, Koubaa, Sant'Ana, \& Orlien, 2016). Furthermore, these technologies present selectivity for target compounds that influence the extractions yields.

So that we can start to have zero waste and with the maximum value, thus taking advantage of the potential of by-products. Moreover, as the use of these techniques for extraction is still very little used, in many of them, their effects are not known, not only at the organoleptic level but also their impact on phytochemicals that allow their food, cosmetic, pharmaceutical use, among others (Gómez-García et al., 2020; Zinoviadou et al., 2015).

Among the natural products recovered from agro-industrial byproducts, the polysaccharides are of significant interest, due to their physical-chemical and biological properties, namely prebiotic, antiinflammatory, anticancer, and antioxidant activities, and applications for example in the formulation of vaccines (Beres et al., 2016; Gullón et al., 2020). Also, antioxidant compounds (e.g. vitamins, polyphenols) are other interesting BCs due to their ability to delay or to prevent the production of free radicals or to protect cells from their harmful effects (Afonso et al., 2014; Barba et al., 2016).

Grapes are one of the most widely produced fruit in the world, with approximately 75 million tonnes produced each year. Their production is ed towards fresh consumption as table fruit, juice, and raisins, but the principal use is in winemaking, a relevant traditional activity in several European countries. The wine agro-industrial sector is a significant player in the Portuguese economy as the country is the 11th largest producer of wine and the 10th exporter worldwide (OIV, 2018). As a consequence, high amounts of by-products are generated with associated economic and environmental costs (Charis M. Galanakis, 2015a; Karovičová, Kohajdová, Minarovičová, \& Kuchtová, 2015). These by-products are often underexploited, and their potential value is frequently lost. Nevertheless, these by-products can be used as a source of high-value materials, thus avoiding thermal destruction or sending them to disposal. These by-products should be adding value to the industry using environmentally friendly methods and in line with the new philosophies on sustainable industrial development (Chemat et al., 2020; Kalli et al., 2018).

Various benefits are associated with the application of a recovery strategy: help in the reduction of by-products that accumulate in the vinification process (causing pollution problems); producers would getting advantages from decreasing disposal costs of waste and the opportunity of extra-income; consumers and industries would profiting from the application of some BCs (Barba et al., 2016; Maroun, Rajha, Vorobiev, \& Louka, 2017).

The standard vinification procedure follows a multiple-step process, including destemming, crushing, storage, screening, fermentation, maturation, stabilization, and bottling (see Fig. 2).

Grape (Vitis vinifera L.) pomaces are the major by-products generated in the winemaking process, with 23 million tons produced in Europe (García-Lomillo \& González-SanJosé, 2014). They consist of skins, pulp, seeds, in some cases, stems being is used to extract grape seed oil (see Fig. 3). A distinct winery by-product may be grape marc that only contains skins and pulp (O'Shea, Arendt, \& Gallagher, 2012).

The by-products generated in this process are also rich in BCs, namely fiber, phenolic compounds (tannins, phenolic acids, anthocyanins, resveratrol), proteins, lipids, carbohydrates, vitamins, and minerals (O'Shea et al., 2012; Sousa et al., 2014). The characteristics of BCs present in grape pomace depend on the grape cultivar, grape pre- and post-harvest conditions, and processing conditions. They may exert beneficial effects as antioxidants, antimutagens, and anti-tumoral agents and anti-inflammatory modulators (Karovičová et al., 2015).

Grape pomace has been reported as a rich source of dietary fiber (mainly cellulose, small proportions of pectins, and hemicelluloses) (O'Shea et al., 2012). Nevertheless, concerning grape skin, there is a lack of knowledge about the composition and structure of its chemical components.

Therefore, grape by-products constitute a promising source of BCs (Table 1) that can be used for their nutritional properties and biological potential with nutritional and pharmaceutical applications (e.g., anticancer, anti-inflammatory, cardiovascular prevention) (Hogervorst, Miljić, \& Puškaš, 2017; Ianni \& Martino, 2020; Karnopp, Margraf, Maciel, Santos, \& Granato, 2017). Also, given the current situation of COVID, they also can strengthen the immune system, which is fundamental to the response to the virus, although new studies must be 


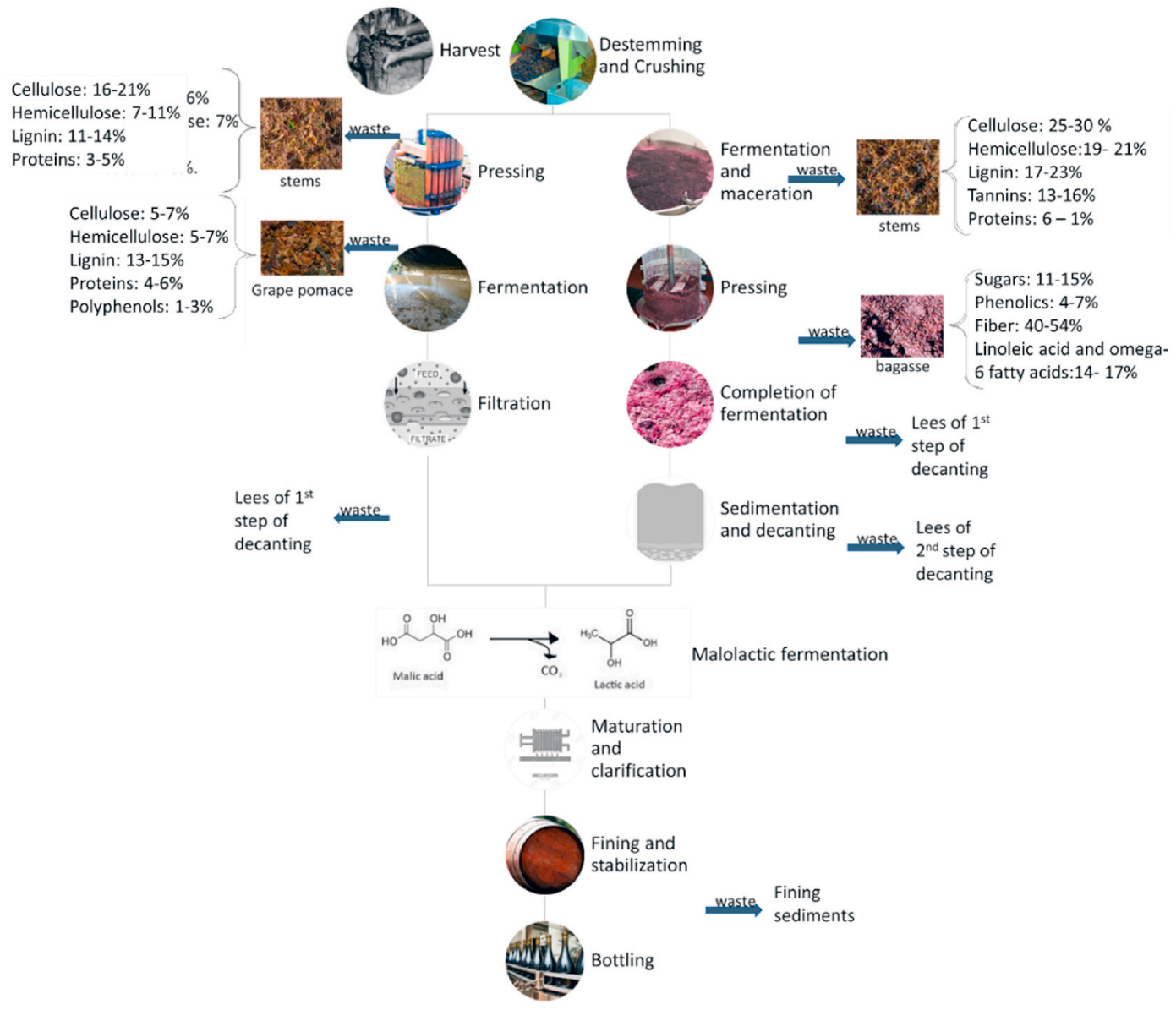

Fig. 2. By-products generation during winemaking process based from Hogervorst et al., 2017 and Prozil, Evtuguin, \& Lopes, 2012.

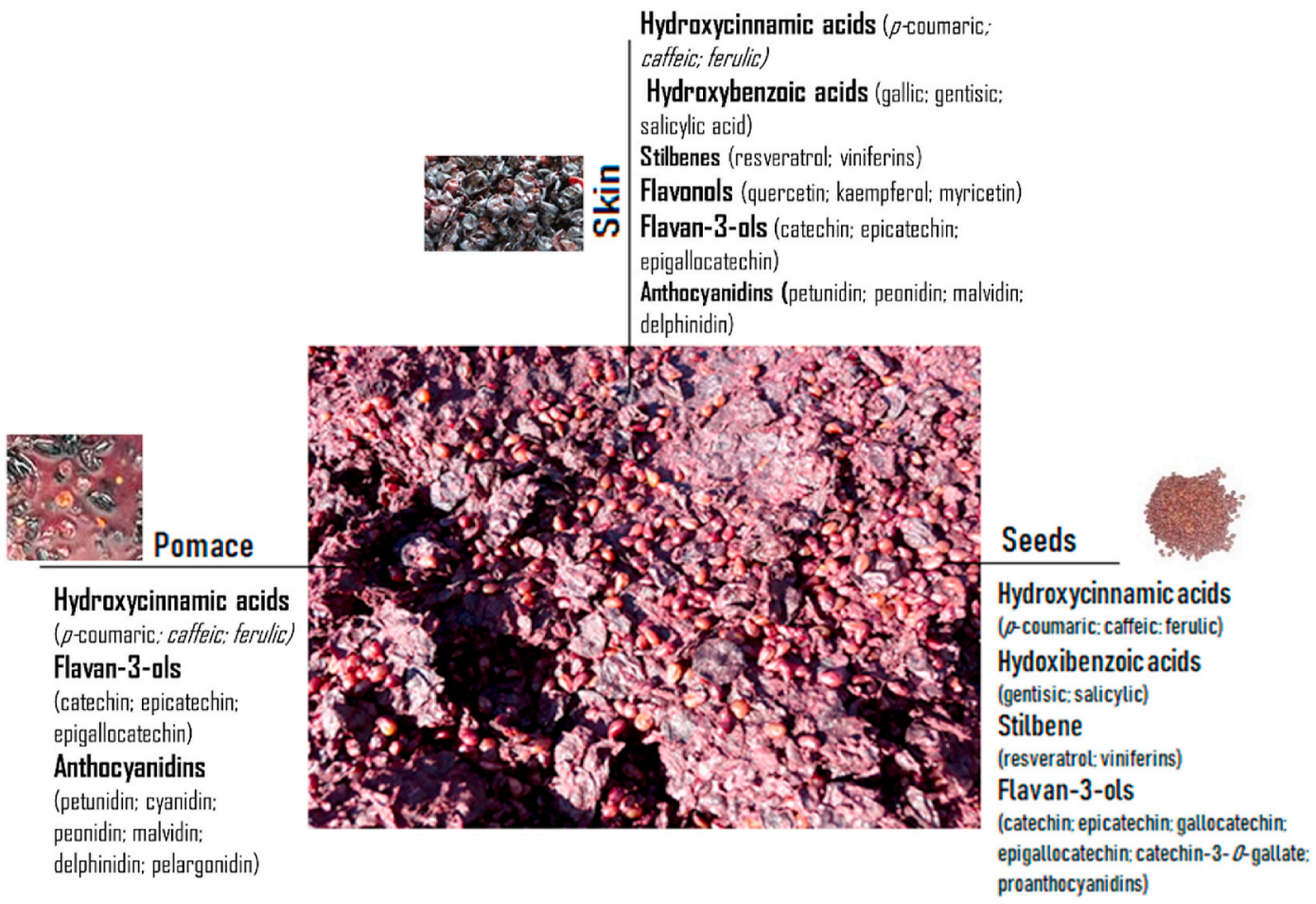

Fig. 3. Pomace of red grapes (seeds, pulp and skins). (For interpretation of the references to color in this figure legend, the reader is referred to the Web version of this article.) 
Table 1

Chemical Composition of grape by-products concerning Fiber, Proteins, Minerals, Vitamins, and Polyphenols (\%).

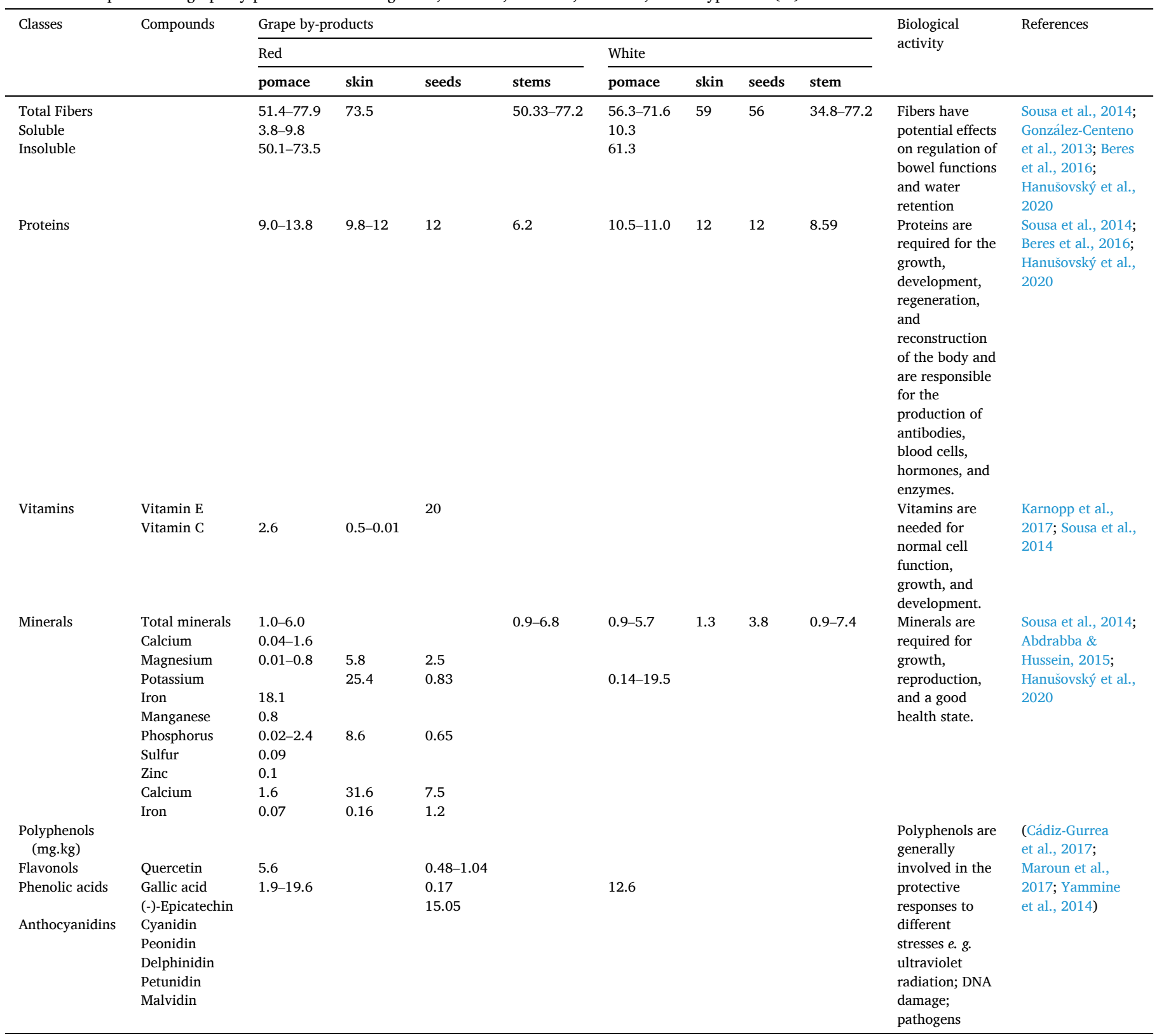

performed to specifically demonstrate this action (Galanakis, 2020).

\subsection{Grape dietary fiber}

According to CODEX, dietary fiber is a group of food components, which is resistant to hydrolysis by human digestive enzymes and may have one or more physiological and health benefits. It consists of carbohydrate polymers with ten or more monomeric units, polysaccharides, oligosaccharides, and lignin (see Fig. 4) (Karovičová et al., 2015).

Several studies described in Table 1, report the presence of dietary fiber in grapes and its by-products, ranging from 51.4 to $83.6 \%$ dry matter (DM). Moreover, there is no indication of significant differences in the amount of total fiber between red and white grape cultivars (Afonso et al., 2014; Apolinar-Valiente et al., 2015; Beres et al., 2016; González-Centeno et al., 2013; Karovičová et al., 2015; O'Shea et al., 2012). Nonetheless, differences were found among insoluble and soluble fractions content from white or red grape pomace. The insoluble fiber was constituted mainly by cellulose, hemicellulose, and lignin, representing 61.3 and 73.5 of total fiber in white and red grape pomace, respectively, while the soluble fraction is mainly constituted by uronic acids and contains 3.7 and $10.3 \%$ of the fiber in red or white, respectively (Sousa et al., 2014). Indeed, the grape cultivar, growth climate, and processing conditions influence the dietary fiber amount.

As it turns out, winemaking by-products are a rich source of dietary fiber with demonstrated beneficial effects, including the regulation of glucose absorption, obesity prevention, reduction of blood cholesterol, and cardiovascular risk. Besides, grape pomace is a good source of fiber ingredient for the industry with higher potential on the regulation of bowel functions and water retention (Ianni \& Martino, 2020; O'Shea et al., 2012).

\subsection{Proteins, peptides and amino acids}

Food proteins are highly complex biochemical macromolecules with a significant function in many biological processes. Proteins are 


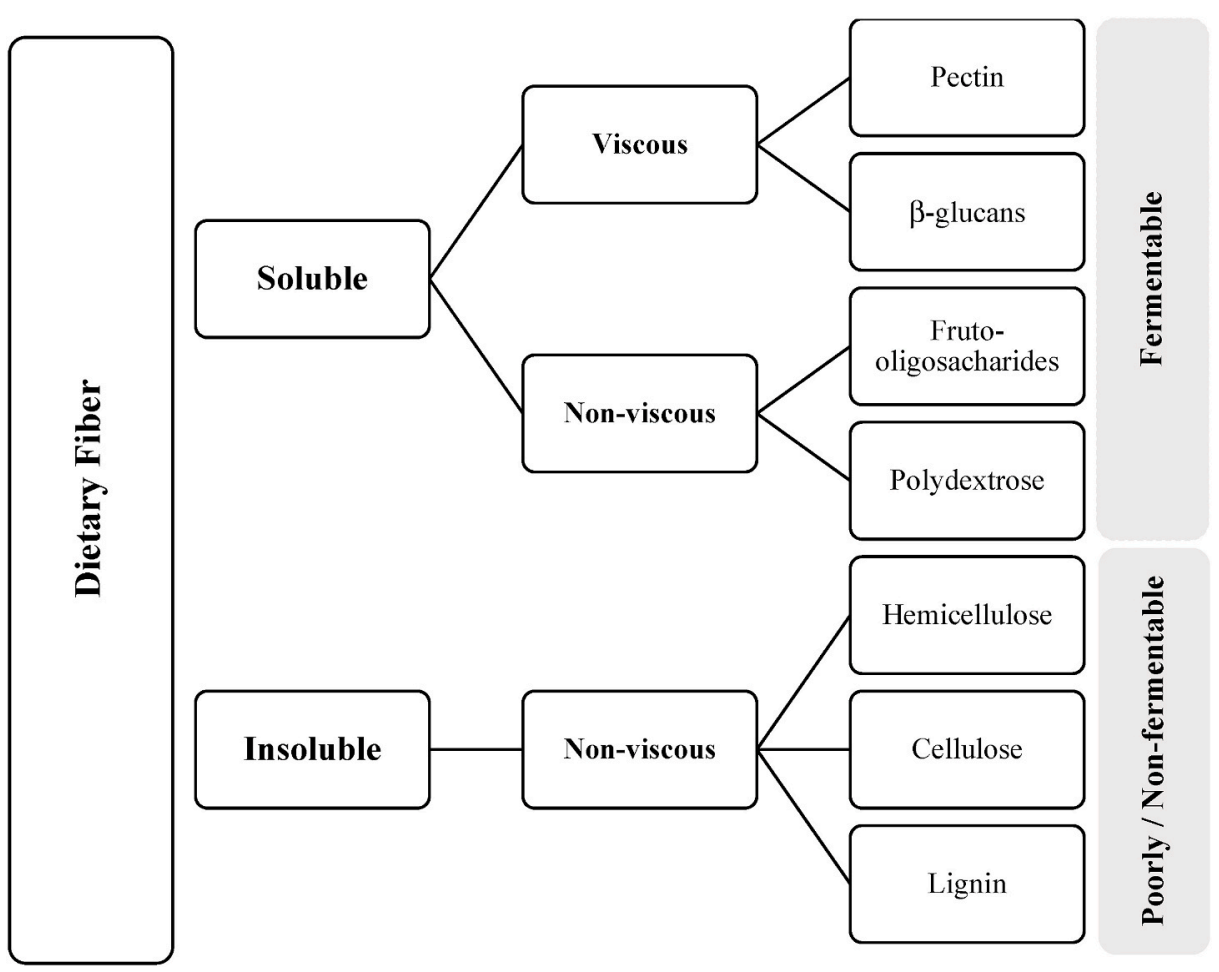

Fig. 4. Based on its chemical properties adapted from Arranz, Medina-Remn, \& Estruch, 2012.

comprised of ca. 20 amino acids and nine of them (essential amino acids) cannot be synthesized by adult humans and must be obtained through the diet (Atanacković Krstonošić et al., 2017).

The properties that govern protein functionality include size, shape, net charge and distribution of charges, polarity, hydrophobicity/hydrophilicity ratio, structure (secondary, tertiary and quaternary), composition, sequence, interaction with other food components, and physical parameters such as $\mathrm{pH}$ and chemical environments (Tahergorabi \& Hosseini, 2017, pp. 15-38).

The predominant proteins found in must and wine are thaumatinlike proteins and chitinases. A bottle deposit is caused by protein aggregation during storage. Regarding white wine, proteins play a significant role in colloidal stability and clarity (Tahergorabi \& Hosseini, 2017, pp. 15-38).

The amounts of proteins reported in grape by-products ranged from 6.2 to $13.8 \%$ of DM (Beres et al., 2016; Hanušovský et al., 2020; Karnopp et al., 2017; Karovičová et al., 2015; Ribeiro, de Lima, Alves, Gonçalves, \& Souza, 2018; Tseng \& Zhao, 2013). This difference depends on both grape cultivar and type of winemaking by-products. While for grape pomace, the red cultivars present superior values of proteins than the white grapes pomace, for stems higher significant values of proteins than the red grapes have been found (Hanušovský et al., 2020).

\subsection{Vitamins}

Vitamins are defined as a heterogeneous group of micronutrients with different structures and functions, which are present in food in small amounts (traces), and that an organism needs in small amounts for normal functioning because they are involved in metabolic reactions; vitamin deficiency causes a number of pathologies or even death. However, as the organism cannot synthesize some vitamins (or in enough quantities), they must be obtained through the diet.

The amount of Vitamin $\mathrm{C}$ in the skin of grapes ranges from 0.5 to $1.2 \%$ of DM, while in grape pomace $2.6 \%$ DM (Sousa et al., 2014).

Vitamin E, also known as tocopherol, is a constituent of grape seeds, varying from 10 to $20 \%$ of $\mathrm{DM}$, and it depends on the grape variety, origin, and environmental growing conditions (de Souza et al., 2020). It acts as a lipid-soluble chain-breaking antioxidant, being involved in the protection of polyunsaturated fatty acids and lipoproteins from lipid peroxidation, preserving the integrity of biological membranes, lipoproteins, and lipid stores against oxidation (Barba et al., 2016; de Souza et al., 2020; Maroun et al., 2017). These mechanisms relate to the prevention of many diseases, such as atherosclerosis, cancer, aging, cataracts. Additionally, animal studies have shown significant anti-inflammatory effects with dietary supplementation containing grape pomace (Kafantaris et al., 2018; Urquiaga et al., 2015).

\subsection{Minerals}

Minerals are micronutrients; some of these considered essential because they are necessary for growth, reproduction, and good health state. Several minerals have been used as components of functional foods due to their demonstrated preventive or therapeutic effects on chronic diseases (Phan-Thien, Wright, \& Lee, 2012).

According to García-Lomillo, González-SanJosé, Del Pino-García, Rivero-Pérez, \& Muñiz-Rodríguez, 2014, the grape by-products, essentially skin and pomace, are rich in minerals. Skin presented $11 \%$ DM of ash content and grape pomace $14 \%$ DM, while seeds presented the lowest ash content ( $3 \% \mathrm{DM})$. Potassium $(\mathrm{K})$ has been reported as the major mineral present in the skin of grape by-products (ranging from 25.4 to $43.0 \% \mathrm{DM}$ ). Other minerals are also found in grape skins, namely calcium (Ca) (with ranges from 20.0 to $31.6 \%$ DM), phosphorous (P) (with ranges from 8.6 to $30.0 \% \mathrm{DM}$ ), and sodium (Na) (with ranges from 0.1 to $10.0 \% \mathrm{DM})$. Relatively to grape pomace, the mineral content includes iron (Fe), K, zinc (ZN), Ca, manganese ( $\mathrm{Mn})$ and phosphorus (1.8; $0.1 ; 0.1 ; 0.04 ; 0.013$ and $2.4 \%$, respectively). Grape seeds present higher amounts of $\mathrm{K}, \mathrm{Na}, \mathrm{Ca}, \mathrm{Mg}$ and $\mathrm{P}$ (ranging from 59.0 to 95.2; 1.9 to 3.4; 52.1 to $60.0 ; 13.8$ to 17.1 and $6.5-42.1 \% \mathrm{DM}$, respectively) (Abdrabba \& Hussein, 2015; García-Lomillo et al., 2014).

As verified before, there are differences in the mineral content of grape by-products associated with the edaphoclimatic conditions, viticultural practices and winemaking process. Besides, the duration and 
type of maceration process (in the winemaking process) have a strong influence on the minerals extraction and reabsorption, conditioning the minerals content of grape by-products (García-Lomillo et al., 2014; Hanušovský et al., 2020).

Essential minerals are also found in vine-shoots, including $\mathrm{Ca}, \mathrm{Fe}, \mathrm{K}$, $\mathrm{Mg}, \mathrm{P}$, and Zn. Other minerals such as N, S, Al, K, and Ca are also found and could be used as fertilizers (Mendívil, Muñoz, Morales, Juárez, \& García-Escudero, 2013). Sánchez-Gómez, Zalacain, Alonso, and Salinas (2014) have studied mineral extraction from Airén vine-shoots suggesting the mineral content are dependents of the extraction technique used, namely conventional solid-liquid extraction (CSLE), solid-liquid dynamic extraction (SLDE-Naviglio), microwave extraction (ME), or pressurized solvent extraction (PSE).

\subsection{Polyphenols}

Polyphenols (mainly flavonoids and anthocyanins) are specific plant secondary metabolites with a phenolic hydroxyl group attached to the aromatic ring. Polyphenols classification is based on their chemical structural similarity (Fig. 5). In this way, four major polyphenols classes can be found: phenolic acids, flavonoids, lignans, and stilbenes (Ianni \& Martino, 2020; Namir, Siliha, \& Ramadan, 2015).

Polyphenols exist in structures, such as vacuoles of plant cells and lipoproteins bilayers, which are not accessible to solvents (Boussetta, Grimi, \& Vorobiev, 2015; Parniakov, Barba, Grimi, Lebovka, \& Vorobiev, 2016). Thus, their recovery is complicated, and usually, the conventional method to extract polyphenols is based on a solid-liquid solvent extraction.

Several epidemiological studies have demonstrated that polyphenols have anti-inflammatory, anti-viral, anti-tumoral, furthermore prevent heart diseases and cancers (Boussetta et al., 2015).

The potential health benefits of these BCs and the increasing interest in the biopreservation of food components represent a challenge towards improving traditional heat-based methods (which may also lead to loss of BCs) (Deng et al., 2015; Kalli et al., 2018). Nevertheless, these traditional technologies may lead to the loss of BCs; thus it is imperative to develop new, less aggressive and cleaner processing technologies to allow the BCs application in the formulation of different food (e.g. colorants and antioxidants) (Galanakis, 2018) and pharmaceutical products (e.g. nutraceuticals) (Barba, Galanakis, Esteve, Frigola, \& Vorobiev, 2015).

Among fruits, grapes are one of the significant sources of polyphenols, and they are mainly present in their skins, seeds, and short stems. Grape pomace is still rich in secondary metabolites, including phenolic acids and flavonols, and they differ due to the grape variety (Ianni \& Martino, 2020). The main polyphenols present in red grape pomace are anthocyanins, flavonols, and phenolic acids. The main monomeric anthocyanins include 3-O-monoglucosides of the five free anthocyanidins, namely, cyanidin-3-O-glucoside, peonidin-3-O-glucoside, delphinidin-3-O-glucoside, petunidin-3-O-glucoside, and malvidin-3-O-glucoside, representing $46.5-50.0 \%$ of the anthocyanins available. Quercetin is the main flavonol $(0.92-5.66 \% \mathrm{DW})$ and gallic acid (1.9-19.7\% DW) the main phenolic acid present (O'Shea et al., 2012). As a supplement to the effect of the grape cultivar, the winemaking process also influences the individual compounds, including the polyphenols content. In contrast to red pomace, the white grape by-products are exposed to short-time maceration and leaving little time for the extraction of soluble polyphenols. The polyphenolic compounds that are mainly present are (+)-catechin, (-)-epicatechin, and (-)-epicatechin-3-O-gallate (González-Centeno et al., 2013).

Relatively to grape seeds, the principal flavonoids that could be found are (-)-epicatechin, catechin, epicatechin gallate, and dimeric procyanidins B1 and B2 (Cádiz-Gurrea et al., 2017; de Souza et al., 2020).

\subsection{Lignans}

The lignans are monolignol dimers from hydroxycinnamic acids ( $p$ coumaric, ferulic and sinapic acids) bonded at carbon $8\left(\mathrm{C}_{8}-\mathrm{C}_{8}\right)$. They are considered as bioactive, non-nutrient, non-caloric phenolic plant

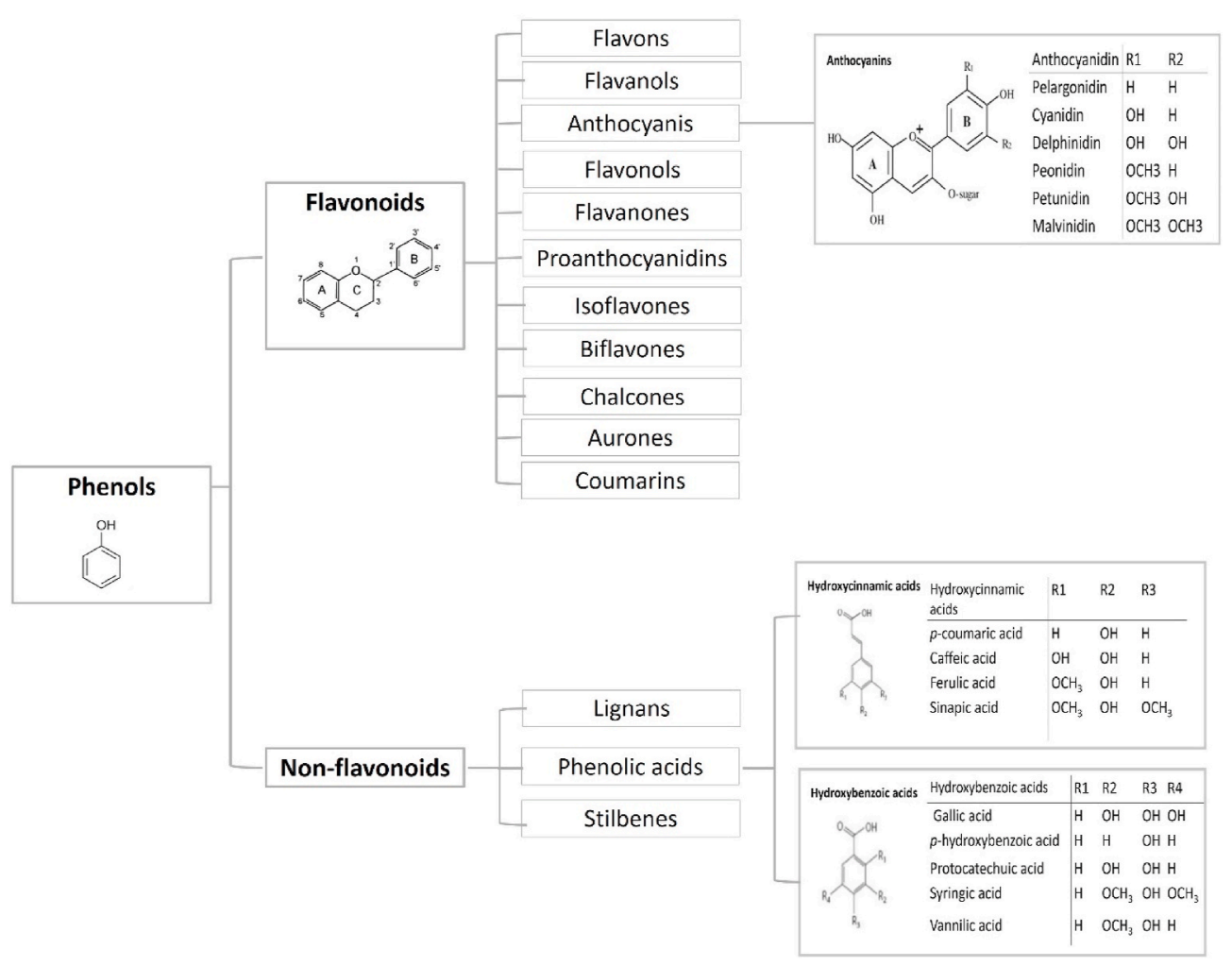

Fig. 5. Classification of polyphenols of grape by-products according to the solubility. 
compounds (Peterson et al., 2010).

The lignan content in grapes is approximately $130 \mu \mathrm{g}$ per $100 \mathrm{~g}$, and the predominant lignan compounds presents are lariciresinol, matairesinol, pinoresinol, secoisolariciresinol, syringaresino and medioresinol (Peterson et al., 2010).

\subsection{Stilbenes}

Stilbene are organic compounds with aromatic groups bond to each end of a carbon-carbon double bond. They derived from the phenylpropanoid pathway (present in many plant families). These compounds can be found in the wine by-products such as stems, leaves, and berries. They deriving from trans-resveratrol (3,5,4'-trihydroxystilbene) and occur as glucosylated derivatives, or oligomeric forms denominated viniferins (Ianni \& Martino, 2020; Piñeiro, Marrufo-Curtido, Vela, \& Palma, 2017).

\section{Recovery of BCs from by-products}

As mentioned above, grape by-products have beneficial properties conferred by their BCs content. Thus, it is imperative to minimize the adverse effects of the extraction and recover as much as possible without losing those BCs and consequently, its beneficial properties (Galanakis, 2012). The recovery strategy must aim a final purpose:

- maximizing yield extraction of target compounds
- adaptation of the extraction process to the demands of industrial
processing
- purification of high added-value BC from co-extracted compounds,
impurities, and toxics
- avoid deterioration, autoxidation, and reduction in BC functional
properties
- ensure the food grade characteristics of the final product and the
sustainability of the process within the food industry.

Different steps are needed to extract BCs from food by-products, and these follow the rules of advanced analytical chemistry (Deng et al., 2015; Galanakis, 2012), with progress from the macroscopic to the macromolecular level and afterwards to the recovery (extraction, removal) of specific BCs(Deng et al., 2015; Galanakis, 2013; Martillanes, Rocha-Pimienta, \& Delgado- Adámez, 2018). In case of fruits (solid by-products) it includes a pre-treatment of by-product (e.g. milling the by-product) to allow better recovery followed by extraction of homogeneous grape by-products; purification of extracts and finally drying of purified extracts, see Fig. 1, (Galanakis, 2012, 2013, 2015a).

Extraction and separation constitute a critical issue for the rational valorisation of agro-food by-products (Galanakis, 2015b). The extraction process depends not only on the qualitative and quantitative composition of the extracts from grape by-products, the source of the plant material and the tissue considered (leaves, stems, seeds, peels) but also on the physical and chemical properties of the desired compounds, i.e., solubility, polarity, hydrophobicity and thermal stability (Hogervorst et al., 2017; Manna, Bugnone, \& Banchero, 2015; Yammine, Ghidossi, \& Mietton-Peuchot, 2014).

The principal advantage of this recovery strategy is the capacity of simultaneous extraction of several ingredients in various streams, which means that micromolecules, such as polyphenols, can be recovered with an ethanolic extraction. At the same time, the macromolecules, like pectin, can be a recovered in the insoluble ethanol residue. On the other hand, if the target compound is just a macromolecule, such as protein, the second stage could be omitted (Galanakis, 2015a; 2015b). These methods typically comprise water or organic solvent extraction (percolation, infusion, steam distillation, soxhlet extraction), supercritical $\mathrm{CO}_{2}$ extraction, pressurized liquid extraction, and microwave-assisted extraction (Table 2).

\subsection{Solid-liquid extraction}

Solid-liquid extraction (SLE) implies the contact of the solid material matrix with a liquid solvent and allows soluble components to be separated from solids (Baiano, 2014; Barba et al., 2016).

It is one of the most used techniques in the industry to obtain anthocyanins, usually with hydroalcoholic mixtures, being ethanol the preferred alcohol when the product is for human consumption (Galanakis, 2012, 2015a).

The selection of the solvents must be carefully made considering the chemical and physical properties of the target substances to eliminate or minimize matrix interferences. Experimental parameters (temperature, time, $\mathrm{pH}$ value, solid-to-liquid ratio, particle size, stirring, solvent polarity) must be chosen accurately to facilitate the extraction of the target molecules. This technique is frequently used to extract oils and is not suitable for thermolabile substances (Baiano, 2014).

Disadvantages of solvent extraction are associated with their toxic, inflammable, explosive and hazardous properties, costs, and the long times needed (Table 3 ). Moreover, this process could require a purification stage after extraction, as filtration or centrifugation (Baiano, 2014; Barba et al., 2016). The purification step can be avoided if clean solvents such as water are being used combined with new extraction techniques to extract hydrophobic compounds, such as lycopene (Nagarajan et al., 2019). Nagarajan and co-authors were able to extract lycopene and pectin throughout the formation of the lycopene-pectin complex from pink guava decanter under the hydrated condition (Nagarajan et al., 2019). The extraction involved two steps, in the first step generated the lycopene-pectin colloidal complex, by the mixture of plant sample $(2.5 \mathrm{~g}$ ) with water $(50 \mathrm{~mL})$ into an extraction vessel. This step encompasses an environmental-friendly method, affordable with high recovery yields than others reported in the literature. The second step involved the separation of lycopene and pectin from the colloidal complex, applying organic solvent extraction (e.g., tetrahydrofuran, THF). Although this method uses only $2 \mathrm{~mL}$ to extract, it does not eliminate its use, being necessary to evaporate the organic solvent that may be present in the pectin (fiber). However, it represents a breakthrough for extractions involving hydrophobic compounds, and it uses lesser volumes than other methods. This extraction is believed possible due to the pectin properties, which exist as an emulsifying agent and envelops the lycopene bodies, which may disperse it as emulsions in a water medium (Nagarajan et al., 2019).

Moreover, the development of the lycopene-pectin complex may be associated with the high-methyl esterified pectin, which forms a threedimensional system through hydrophobic interaction; the non-polar methyl ester groups in pectin minimize their contact with water by coalescing with each other (Nagarajan et al., 2019). Intrinsically, the pectin-stabilized emulsions containing the hydrophobic compounds anchored themselves by its non-polar methyl ester groups and established the cross-linked network structure. Eventually, the lycopene-pectin complex is flocculated and recovered as the sediment (Nagarajan et al., 2019). SLE is referred to in some studies to extract BCs from grape by-products. Karacabey and Mazza (2008) optimized the solid-liquid extraction conditions for resveratrol and other phenolic compounds extraction from milled grape canes. To flavonoid's extraction, both ethanol and the temperature are the dominant process variables. Also, the yield extraction of ferulic acid is better at lower temperatures $16.4{ }^{\circ} \mathrm{C}$ and ethanol concentration of $35 \%$. Nevertheless, for trans-resveratrol and other phenolics, some studies refer that the yields increase with ethanol concentration ranging from 50 to $70 \%$ and the highest temperatures $\left(83.6^{\circ} \mathrm{C}\right)$ (Karacabey \& Mazza, 2008).

(Burin, Ferreira-Lima, Panceri, \& Bordignon-Luiz, 2014) studied the effects of different methods of extraction, including, solid-phase extraction on BCs extraction from grape by-products, observing SPE did not recover those hydroxybenzoic acids (gallic acid, protocatechuic acid), flavanols ((-)-epicatechin) and stilbenes (tyrosol). It might be explained by reactions or interactions occurring between compounds 
Table 2

Effects of extraction methods on compounds extracted from grape-by-products.

\begin{tabular}{|c|c|c|c|c|c|}
\hline $\begin{array}{l}\text { Extraction } \\
\text { method }\end{array}$ & $\begin{array}{l}\text { Application } \\
\text { matrix }\end{array}$ & Detected compounds & Mechanisms involved & Effectson grape compounds & References \\
\hline \multirow[t]{5}{*}{ SLE } & Milled grape & Trans-resveratrol; ferulic acid; & & & $\begin{array}{l}\text { Karacabey and } \\
\text { Mazza (2008) }\end{array}$ \\
\hline & $\begin{array}{l}\text { Grape seed } \\
\text { extract and } \\
\text { grape skin }\end{array}$ & Gallic acid; catechin; proanthocyanidins & $\begin{array}{l}\text { The enzymes utilization as a solvent } \\
\text { hydrolyze some or all components } \\
\text { of by-products matrixes and } \\
\text { increase the yields of extraction }\end{array}$ & & $\begin{array}{l}\text { Fernández et al. } \\
\text { (2015) }\end{array}$ \\
\hline & Cannes & $\begin{array}{l}\text { Hydroxybenzoic acid (ellagic; vanillic; } \\
\text { syringic); hydroxycinnamic acid (ferulic; } \\
\text { p-coumaric; caffeic; trans-caftaric); } \\
\text { flavanol ((+)-catechin); flavonol } \\
\text { (quercetin; myricetin; kaempferol); } \\
\text { stilbenes (trans-resveratrol) }\end{array}$ & & $\begin{array}{l}\text { To cause reactions and/or strong } \\
\text { interactions between phenolic } \\
\text { compounds and the solid } \\
\text { materials }\end{array}$ & $\begin{array}{l}\text { (Burin, } \\
\text { Ferreira-Lima, } \\
\text { Panceri, \& } \\
\text { Bordignon-Luiz, } \\
\text { 2014) }\end{array}$ \\
\hline & $\begin{array}{l}\text { Grape seeds } \\
\text { and skins }\end{array}$ & Proanthocyanidins & $\begin{array}{l}\text { Authors utilize enzymes to increase } \\
\text { the yield extraction, cellulase, } \\
\text { tannase, pectinases mixture }\end{array}$ & $\begin{array}{l}\text { The links between polyphenols } \\
\text { and polysaccharides are broken }\end{array}$ & $\begin{array}{l}\text { Fernández et al. } \\
\text { (2015) }\end{array}$ \\
\hline & $\begin{array}{l}\text { Winegrapes } \\
\text { skin }\end{array}$ & $\begin{array}{l}\text { Anthocyanins, flavonols reactive to } \\
\text { vanillin, proanthocyanidins }\end{array}$ & & & Benucci et al. (2017) \\
\hline \multirow[t]{4}{*}{ MAE } & Grape seeds & Polyphenols & & $\begin{array}{l}\text { Tissue disruption and compounds } \\
\text { extraction into solvent }\end{array}$ & Li et al. (2011) \\
\hline & Grape skins & Anthocyanins & $\begin{array}{l}\text { Higher significant influence of } \\
\text { solvent extrcation; MAE allows } \\
\text { recover acyl derivates, while with } \\
\text { conventional methods application } \\
\text { lowest levels of these compounds } \\
\text { may be extracted }\end{array}$ & & Liazid et al. (2011) \\
\hline & $\begin{array}{l}\text { Grape juice } \\
\text { wastes }\end{array}$ & Anthocyanins & $\begin{array}{l}\text { The antioxidant capacity increases } \\
\text { progressively with the application } \\
\text { up to } 400 \mathrm{w} \text { and decays when this } \\
\text { voltage is exceeded }\end{array}$ & $\begin{array}{l}\text { Osmotic effect; cell rupture, } \\
\text { compounds diffusion into solvents } \\
\text { and an effectiveness extraction }\end{array}$ & $\begin{array}{l}\text { Varadharajan et al. } \\
\text { (2017) }\end{array}$ \\
\hline & $\begin{array}{l}\text { Grape skin } \\
\text { Grape pomace }\end{array}$ & $\begin{array}{l}\text { Total phenols } \\
\text { Polyphenols; Anthocyanins }\end{array}$ & $\begin{array}{l}\text { MAE treatment with } 1.000 \mathrm{~W} \text { of } \\
\text { power and } 10 \text { min time of exposure } \\
\text { increase the polyphenols, including } \\
\text { anthocyanins recovery }\end{array}$ & Grape pomace & $\begin{array}{l}\text { Kwiatkowski et al. } \\
\text { (2020) }\end{array}$ \\
\hline \multirow[t]{5}{*}{ SFE } & Grape skins & Polyphenols & $\begin{array}{l}\text { Use co-solvents increase the SFE } \\
\text { efficiency }\end{array}$ & & Ghafoor et al., 2010 \\
\hline & Grape pomace & & & & Oliveira et al. (2013) \\
\hline & Grape seeds & Total polyphenols & & $\begin{array}{l}\text { High pressure and temperature } \\
\text { increase the co } 2 \text { solvating power } \\
\text { Temperatures higher than } 50^{\circ} \mathrm{c} \\
\text { may cause the polyphenolic } \\
\text { compounds denaturation }\end{array}$ & Manna et al. (2015) \\
\hline & Grape skins & Total anthocyanins & & $\begin{array}{l}\text { Improve both solute solubility and } \\
\text { the diffusion coefficient }\end{array}$ & \\
\hline & Grape seeds & $\begin{array}{l}\text { Flavonol (quercetin-3- } \beta \text {-d-glucoside); } \\
\text { phenolic acids (caffeic acid; trans-ferulic } \\
\text { acid; } p \text {-coumaric acid; trans-cinnamic } \\
\text { acid); flavanol ((-)-epicatechin; } \\
\text { (+)-catechin; naringenin); stilbene } \\
\text { (resveratrol); isoflavone (formononetin) }\end{array}$ & & & de Souza et al. (2020) \\
\hline \multirow[t]{2}{*}{ PHWE } & Grape pomace & Proanthocyanidin & & $\begin{array}{l}\text { Degradation of proanthocyanidin: } \\
\text { pyrilium ring of anthocyanins; } \\
\text { sugar moiety reactions }\end{array}$ & $\begin{array}{l}\text { Vergara-Salinas et al. } \\
\text { (2013) }\end{array}$ \\
\hline & Grape pomace & $\begin{array}{l}(+) \text {-catechin, }(-) \text {-epicatechin, kaempferol } \\
\text { and myricetin, and hydroxymethylfurfural } \\
(5-\mathrm{hmf})\end{array}$ & & Breakdown tannin bonds & $\begin{array}{l}\text { Vergara-Salinas } \\
\text { et al., } 2015\end{array}$ \\
\hline \multirow[t]{4}{*}{ PEF } & $\begin{array}{l}\text { Grape by- } \\
\text { products }\end{array}$ & Total phenolic content & & & $\begin{array}{l}\text { (Corrales, Toepfl, } \\
\text { Butz, Knorr, \& }\end{array}$ \\
\hline & & Anthocyanins monoglucosides & & $\begin{array}{l}\text { PEF application allows the } \\
\text { substitution pattern of bring in the } \\
\text { flavylium structure, as well as the } \\
\text { different glycosilation of a and c } \\
\text { rings }\end{array}$ & Tauscher, 2008) \\
\hline & Grape skins & & & $\begin{array}{l}\text { Skin tannins depolymerization } \\
\text { Vacuolar tannins modification }\end{array}$ & $\begin{array}{l}\text { (El Darra et al., 2013) } \\
\text { Barba et al. (2016) }\end{array}$ \\
\hline & Grapes & Anthocyanins and tannins & $\begin{array}{l}\text { Electroporation effect by the } \\
\text { increase of specific energy and the } \\
\text { intensity PEF treatment }\end{array}$ & $\begin{array}{l}\text { Low molecular weight phenolic } \\
\text { compounds released might be } \\
\text { easily oxidized; } \\
\text { PEF may create larger pores in cell } \\
\text { membranes, releasing large and } \\
\text { more complex phenolic molecules } \\
\text { protecting anthocyanins towards } \\
\text { oxidation. }\end{array}$ & $\begin{array}{l}\text { Comuzzo et al. } \\
\text { (2020) }\end{array}$ \\
\hline
\end{tabular}


Table 3

Green technologies aspects, comparison between methods, dvantages and disadvntages of emerging technologies extraction adapted from Khan 2018.

\begin{tabular}{|c|c|c|c|c|c|c|c|c|c|c|c|}
\hline Methods & $\begin{array}{l}\text { Major } \\
\text { Applications }\end{array}$ & $\begin{array}{l}\text { Temperature } \\
\left({ }^{\circ} \mathrm{C}\right)\end{array}$ & $\begin{array}{l}\text { Pressure } \\
(\mathrm{atm})\end{array}$ & $\begin{array}{l}\text { Energy } \\
\text { imput }\end{array}$ & Solvent & $\begin{array}{l}\text { No. of } \\
\text { Stage }\end{array}$ & $\begin{array}{l}\text { Extraction } \\
\text { Time }\end{array}$ & $\begin{array}{l}\text { "green" } \\
\text { characteristics }\end{array}$ & Advantages & Disadvantages & References \\
\hline Conventional & $\begin{array}{l}\text { Plant samples, } \\
\text { essential oils }\end{array}$ & $25-200$ & $1 \mathrm{~atm}$ & $\begin{array}{l}20 \text { to } \\
2000 \\
\mathrm{KJ} / \mathrm{Kg}\end{array}$ & organic & $1-5$ & & not applied & $\begin{array}{l}\text { Commonly used; easiest } \\
\text { method }\end{array}$ & $\begin{array}{l}\text { Chances of impurities; } \\
\text { Introduction of } \\
\text { Analytical errors }\end{array}$ & Deng et al. (2015) \\
\hline PHWE & $\begin{array}{l}\text { Plant samples, } \\
\text { medicinal } \\
\text { compounds }\end{array}$ & $100-374$ & 10-200atm & & Water & 1 & $3 \min -150 \mathrm{~min}$ & $\begin{array}{l}\text { shorter extraction } \\
\text { time with higher } \\
\text { extraction yields }\end{array}$ & $\begin{array}{l}\text { Less solvent; Less time of } \\
\text { extraction }\end{array}$ & $\begin{array}{l}\text { No suitable for } \\
\text { thermolabile compounds }\end{array}$ & $\begin{array}{l}\text { (Bursać Kovačević } \\
\text { et al., 2018) }\end{array}$ \\
\hline MAE & $\begin{array}{l}\text { Essential oils, } \\
\text { thermolabile } \\
\text { compounds }\end{array}$ & $25-70$ & $\begin{array}{l}1-1000 \\
\mathrm{~atm}\end{array}$ & & Organic & $1-5$ & $15 \mathrm{~min}-120 \mathrm{~min}$ & $\begin{array}{l}\text { minimized solvent } \\
\text { amounts, thus } \\
\text { reducing } \\
\text { waste production or } \\
\text { the emission of } \mathrm{CO} 2 \text {, }\end{array}$ & $\begin{array}{l}\text { Shorter extraction times; lower } \\
\text { volumes of solvent; Speed } \\
\text { uniformity of heating (in some } \\
\text { cases this uniformity may be } \\
\text { reduced); Selective heating } \\
\text { (microwaves couple selectively } \\
\text { into materials that are more } \\
\text { absorptive of the energy } \\
\text { although greater efficiency can } \\
\text { be achieved, temperature } \\
\text { profiles can develop in multi- } \\
\text { component food systems); Can } \\
\text { be turned on or off instantly; } \\
\text { Colors, flavors, and nutrients } \\
\text { are preserved; }\end{array}$ & $\begin{array}{l}\text { Lack of experimental } \\
\text { data needed to model } \\
\text { MW heating; The need } \\
\text { for engineering } \\
\text { intelligence to } \\
\text { understand and } \\
\text { minimize uneven } \\
\text { heating or thermal } \\
\text { runaway; High capital } \\
\text { cost }\end{array}$ & $\begin{array}{l}\text { Li et al., 2011; } \\
\text { Liazid et al., 2011; } \\
\text { (Varadharajan et al., } \\
\text { 2017) }\end{array}$ \\
\hline SFE & $\begin{array}{l}\text { thermolabile } \\
\text { compounds }\end{array}$ & $31.1<$ & 73atm $<$ & $\begin{array}{l}32- \\
254 \mathrm{KJ} / \\
\mathrm{Kg}\end{array}$ & $\mathrm{CO} 2$ & $\begin{array}{l}1 \\
\text { (recycled) }\end{array}$ & $10 \mathrm{~min}-60 \mathrm{~min}$ & $\begin{array}{l}\text { higher temperature } \\
\text { and pressure allow } \\
\text { recover polar and } \\
\text { non-polar molecules } \\
\text { with water }\end{array}$ & $\begin{array}{l}\text { Solvent has a low critical point } \\
\text { of pressure and temperature } \\
\left(31{ }^{\circ} \mathrm{C} \text { and } 7.3 \mathrm{MPa} \text { ); It is non- }\right. \\
\text { toxic, non-flammable, } \\
\text { nonexplosive, and it is } \\
\text { considered as a food-grade } \\
\text { solvent (GRAS); CO2 is non- } \\
\text { reactive, non-toxic, easily } \\
\text { available and less costly; } \\
\text { Contain exceptional mass } \\
\text { transfer properties; } \\
\text { environmentally friendly and } \\
\text { energy-efficient process; } \\
\text { sustainable solvent easy to } \\
\text { obtain, cheap, and it allows to } \\
\text { obtain a solvent-free extract }\end{array}$ & $\begin{array}{l}\text { High pressures increase } \\
\text { the process costs; Polar } \\
\text { extracts are not soluble } \\
\text { in the } \mathrm{CO} 2 \text { mobile phase }\end{array}$ & $\begin{array}{l}\text { Ghaffor et. Al. 2010; } \\
\text { Oliveira et al., 2013; } \\
\text { Manna et al., 2015; }\end{array}$ \\
\hline PEF & $\begin{array}{l}\text { thermolabile } \\
\text { compounds }\end{array}$ & $25-150$ & $1 \mathrm{~atm}$ & $\begin{array}{l}1 \text { to } \\
800 \mathrm{KJ} / \\
\mathrm{Kg}\end{array}$ & $\begin{array}{l}\text { organic/ } \\
\text { water }\end{array}$ & 1 & $2 \min -60$ in & $\begin{array}{l}\text { shorter extraction } \\
\text { time with higher } \\
\text { extraction yields; low } \\
\text { energy consumption }\end{array}$ & $\begin{array}{l}\text { No toxicity; short treatment } \\
\text { time; }\end{array}$ & $\begin{array}{l}\text { Difficult to use with } \\
\text { conductive materials }\end{array}$ & $\begin{array}{l}\text { Baiano, 2014; Barba } \\
\text { et al., } 2016\end{array}$ \\
\hline $\mathrm{OH}$ & $\begin{array}{l}\text { thermolabile } \\
\text { compounds }\end{array}$ & 25-150 & $1 \mathrm{~atm}$ & $\begin{array}{l}30 \text { and } \\
180 \mathrm{~kJ} / \\
\mathrm{kg}\end{array}$ & water & 1 & $1 \mathrm{~min}-60 \mathrm{~min}$ & $\begin{array}{l}\text { shorter extraction } \\
\text { time; low energy } \\
\text { consumption with } \\
\text { higher extraction } \\
\text { yields and at the } \\
\text { same time microbial } \\
\text { inactivation; }\end{array}$ & $\begin{array}{l}\text { Reduced maintenance costs } \\
\text { because the lack of moving } \\
\text { parts; no residual heat transfer } \\
\text { after shut off of the current; low } \\
\text { maintenance costs and high } \\
\text { energy conversion efficiencies; } \\
\text { instant shut down of the system; } \\
\text { environmentally friendly } \\
\text { system; reduce the risk of } \\
\text { fouling on heat transfer surface; }\end{array}$ & $\begin{array}{l}\text { Lack of generalized } \\
\text { information } \\
\text { Requested adjustment } \\
\text { according to the } \\
\text { conductivity of the dairy } \\
\text { liquid } \\
\text { Narrow frequency band } \\
\text { Difficult to monitor and } \\
\text { control } \\
\text { Complex coupling } \\
\text { between temperature } \\
\text { and electrical field } \\
\text { distribution }\end{array}$ & $\begin{array}{l}\text { (Coelho, Pereira, } \\
\text { Rodrigues, Teixeira, } \\
\text { \& Pintado, 2019; } \\
\text { Pereira et al., 2016, } \\
\text { 2020; Rocha et al., } \\
\text { 2018) }\end{array}$ \\
\hline
\end{tabular}


and solid materials. Furthermore, the different yields obtained during SLE extraction by several researchers have demonstrated that both phenolic acids and flavonoid extraction are dependent on the type and the concentration of solvent.

Notwithstanding, the interest for improving the extraction yield of target $\mathrm{BCs}$ from agro-industrial by-products and the relevance of the environmentally friendly procedures highlight the need for the introduction of a pre-extraction step combining the application of enzymes, with some studies reporting benefits for winemaking by-products. Fernández, Vega, and Aspé (2015) compared the extraction yield effectiveness of enzymes, like pectinases, cellulases, and tannases, in the proanthocyanidins extraction from grape seeds and skins. They observed an increase of compounds compared to controls. Other authors use $\beta$-glucanase, xylanase, polygalacturonase to extract also polyphenols from winegrapes skins and pomace (Benucci et al., 2017). Despite the high extraction yield and being an environmentally friendly nature, the high costs of the process and the low popularity in the food application has caused disinterest from the industry (Fernández et al., 2015; Gligor et al., 2019)

\subsection{Microwave-assisted extraction}

Microwave-assisted extraction (MAE) is similar to solid-liquid extraction combined with microwave heating (Gligor et al., 2019; Sarfarazi et al., 2020). Nevertheless, it allows increased yields, better process monitoring, and reduces the volume of solvent, extraction time, energy consumption, and cost, which constitute the significant advantages of MAE comparatively to conventional methods (Kwiatkowski, Kravchuk, Skouroumounis, \& Taylor, 2020; Maroun et al., 2017; Sarfarazi et al., 2020).

It is electromagnetic waves, i.e., "an electric and a magnetic field which oscillate perpendicularly to each other at frequencies ranging from 0.3 to $300 \mathrm{GHz}$ " (Baiano, 2014; Chemat et al., 2020). Microwaves interact directly with molecules by ionic conduction and dipole rotation, particularly with polar molecules, to generate heat. The use of microwave energy in combination with temperature and controlled pressure allows high diffusion of fluids and may be applied to different matrices to extract BCs (Galanakis, 2014).

MAE efficiency on compounds extraction depends on factors as power, particle size, irradiation time, and liquid-to-solid ratio. This method can be applied to extract polar molecules, but it is not suitable for dry materials or very wet matrices using non-polar solvents (Ameer, Shahbaz, \& Kwon, 2017; Rocha \& Noreña, 2020).

Grape by-products contain a high amount of water, which efficiently absorbs microwaves' energy and raises internal temperature causing cell disruption and improvement of the extraction compounds. Also, shifting of dissolved ions occurs, allowing the solvent penetration into the internal matrix of samples and consequently allowing higher compounds extraction (Khan et al., 2018; Krishnaswamy, Orsat, Gariépy, \& Thangavel, 2013).

Some studies refer to both advantages and disadvantages of MAE use in the recovery of BCs from grape by-products. MAE conditions applied (power, time, and temperature) can improve the polyphenols' recovery or their degradation (Chemat et al., 2020; Gligor et al., 2019). Varadharajan, Shanmugam, and Ramaswamy (2017) extracted anthocyanins from grape juice wastes with the application of MAE power up to $400 \mathrm{~W}$. Authors observed a gradual increase of Trolox equivalent antioxidant capacity, but when the power exceeded the $400 \mathrm{~W}$, the Trolox equivalent antioxidant capacity value dropped gradually. Other authors reported an improved polyphenols extraction with power increases from 100 to $200 \mathrm{~W}$ and a polyphenols degradation combining temperature increases and power of $200 \mathrm{~W}$. These results may be due by the MAE acceleration of solvent's movement, cell rupture and diffusion of compounds able to be extracted into solvents and consequently an increase in the effectiveness of the extraction of BCs. On the other hand, the increase of MAE power and irradiation time lead to a heating effect and can cause compounds degradation and, consequently, a decrease of phenolic compounds, in this case, glycosidic-bound fractions.

Furthermore, this technique could also cause a reduction of bound phenolic compounds (mainly esterified and glycoside bound phenolic acids), suggesting that MAE could have the capacity to break down -ester and glycoside-bound phenolic acids (Khan et al., 2018). In addition, at low power, higher anthocyanin concentrations were found by other authors. They refers an immediate diffusion of anthocyanins present in the fresh pulp, but when they were present in the skin, other methods were required to make possible their extraction (Chemat et al., 2020). Li, Skouroumounis, Elsey, and Taylor (2011) reported that it is possible a recovery of $90 \%$ of polyphenols from seed grapes in $4.6 \mathrm{~min}$ using MAE, while with conventional techniques are needed much more time (200 $\mathrm{min})$.

The same method was used to extract anthocyanins from grape skins. A fractional experimental design taking into account six variables (solvents, stirring, temperature, time, microwave power, and volume), was performed by Liazid, Guerrero, Cantos, Palma, and Barroso (2011). They determined that the best extraction conditions were $25 \mathrm{~mL}$ of methanol/water $(40 \%), 100{ }^{\circ} \mathrm{C}$ at $500 \mathrm{~W}$ as system power for $5 \mathrm{~min}$, being able to recover acyl derivates (which were not extracted at significant levels with the conventional method). They got these results by a combination of methanol/water as a solvent for anthocyanins extraction, short time extraction, and the power required to recover the anthocyanins.

Piñeiro and their colleagues (2017) used MAE to extract stilbenes from woody vine material. They used $80 \%$ of ethanol in water as solvent at $125^{\circ} \mathrm{C}$ and a time of extraction of $5 \mathrm{~min}$ and yields extraction similar to conventional methods (longer time of extraction).

These enhanced extraction yields of BCs can be attributed to the dipolar molecule's rotation and the solvent heating due to this electromagnetic radiation (Rocha \& Noreña, 2020).

Based on recent studies (Dimić et al., 2020), MAE has been referred for oil extraction from grape seeds. The authors refer to yields superior to the conventional methods (soxhlet) and advantages such as the extraction time and low temperatures that reduce the deterioration of oily compounds. However, more studies are needed to verify the method's ability to isolate purity oils. Overall, the advantage of this method is that the volume of solvent needed and the extraction time are reduced, despite the purification stage after extraction being required as in any other conventional extraction process (Ameer et al., 2017; Baiano, 2014).

Furthermore, it is imperative to establish the process conditions to promote simple tissue disruption and the migration of compounds to the surrounding solvent and consequently obtain higher yields extractions.

Based on studies, the BCs extraction efficiency by MAE can be explained by a fast increase in both temperature and pressure inside the cells. Which, it breaks the cell walls and releases the polyphenols.

\subsection{Supercritical fluid extraction (SFE) SC-CO2 extraction}

Supercritical fluid extraction has been used over the years in different matrices.

Supercritical fluids have characteristics of both gases and liquids and present higher diffusion coefficients, lower viscosity, and surface tension than conventional solvents (Baiano, 2014; Manna et al., 2015). Extraction with supercritical fluids can be done for matrices both in the liquid and in the solid phase, and the extraction selectivity can be controlled by adjusting the temperature, and the pressure of extraction as supercritical fluid dissolving capacity depends on its density. Based on the increase or decrease of temperature, the solubility of extract change, and the extracting agent can be separated from the solvent (Baiano, 2014; Barba et al., 2016). These facts were shown by several authors when applying the SFE to grape by-products (de Souza et al., 2020; Ghafoor, Park, \& Choi, 2010; Manna et al., 2015).

The most used solvent in SFE is carbon dioxide $\left(\mathrm{CO}_{2}\right)$ as it is cheap, 
safe, non-toxic, easy to recycle, and its supercritical conditions may be easily reached. Supercritical extraction $\mathrm{CO}_{2}$ also generates cleaner extracts than other conventional extraction techniques. Nevertheless, in some situations, this technique presented disadvantages due to reduced efficiency extraction compared with conventional techniques, e.g., soxhlet extraction. Moreover, although feasible, longer extraction times were needed leading to a higher $\mathrm{CO}_{2}$ consumption to obtain higher yields of polyphenols from grape skin (Manna et al., 2015). SFE could be modified by co-solvents (ethanol) to change its polarity and increase extraction's yields (Baiano, 2014). Several researches have used this method to improve BCs extraction. Ghafoor et al. (2010) reported that the use of co-solvents is essential to get polyphenols from grape skins and established the need to use ethanol concentrations higher than $6 \%$ to improve the SFE efficiency. In addition, Oliveira et al. (2013) applied this technique on grape pomace showing an enhanced extraction yield with an increase of ethanol concentration up to $15 \%$. However, the increase of ethanol concentration did not necessarily result in higher extraction efficiency, for instance, a decrease of extraction yield by $30 \%$ at higher concentrations was observed in the same study (Manna et al., 2015). These contradictory results reported by researches in the literature could be related to $\mathrm{CO}_{2}$ saturation -with ethanol increased at precise system conditions of temperature and pressure-; the ethanol effect - the hydrogen from ethanol molecule $\left(\mathrm{C}_{2} \mathrm{H}_{6} \mathrm{O}\right)$ forms hydrogen bonds with the oxygen of other molecules. Thus, when the solution has higher ethanol concentration, the energy to separate ethanol molecules is not enough, and it causes a decrease of extraction and, consequently, a decrease in process yield.

In the case of total polyphenols and anthocyanin's extraction, both $\mathrm{CO}_{2}$ temperature and pressure cause significant effects $(p<0.05)$ (Ghafoor et al., 2010). The possible explanation is the increase in the solvating power of $\mathrm{CO}_{2}$ with higher pressures and temperatures. Also, the increase of temperature could improve the polyphenols extraction by enhancing both solute solubility and the diffusion coefficient. However, temperature cannot be increased indefinitely, since the polyphenols degradation may occur for temperatures above $50{ }^{\circ} \mathrm{C}$.

This technique also has the high potential for oil recovery from grape seeds. Dimić et al. (2020), examined how SFE operating parameters affect fatty acid profiling, comparing with conventional technique soxhlet extraction and green methodologies, such as UAE and MAE, accounting for yields and lipophilic antioxidant potential. Regarding the oil seeds profile, they showed that the increase in pressure decreases the total tocopherol, while the increase in temperature increases the content of this compound. This highest tocopherol content could be explained by the promotion of higher solubility of the solute associated to temperature increase, which enhances the mass transfer of a solute from the matrix to the SFE solvent.

\subsection{Pressurize hot water extraction}

The Pressurized Hot Water Extraction (PHWE) has gained popularity in the last decade due to its eco-friendly nature. This process uses pressurized hot water or even steam too, a relatively cheap solvent, under controlled pressure, temperature conditions $\left(100{ }^{\circ} \mathrm{C}\right.$ to critical temperature $\mathrm{Tc}$ ), flow rate and additives to recover compounds from plants, food matrix, and some chemical mixtures. Compared to conventional extraction methods used in the industry, this method is faster. Nevertheless, more studies are necessary for industry scale-up (Bursać Kovačević et al., 2018; Teo, Tan, Yong, Hew, \& Ong, 2010).

The PHWE method comprises four steps: 1) desorption of solutes from different active sites in the sample matrix under the pressurized and highest temperature conditions; 2) diffusion of recovery fluid into the matrix; 3) breaking of bonds between the solute and the matrix and release to the extraction solvent; 4) solutes removing from system throughout chromatographic elution (Teo et al., 2010).

Several authors refer to the highest total phenolic extraction with a temperature increase with the PHWE process (Bursać Kovačević et al.,
2018; Teo et al., 2010). The application of higher temperatures can promote complete cell disruption (Teo et al., 2010) by the hydrolytic reactions promoted by the increase in ionization constant of water at subcritical conditions. Furthermore, it also conduces to plant cell wall components degradation, such as lignin's into phenols; the water polarity decrease (low dielectric constants), promoting the total phenolic compounds solubilization (Bursać Kovačević et al., 2018).

It allows better diffusion rates, and consequently, reaction and extraction rates. Also, it presents lower surface tension and a better solubility to less polar compounds (Bursać Kovačević et al., 2018; Teo, Tan, Yong, Hew, \& Ong, 2010).

The method also can be applied to hydrophobic compounds extraction, like carotenoids, chlorophylls. Bursać Kovačević et al. (2018) refers to the possibility to extract chlorophyll with a maximum at $160{ }^{\circ} \mathrm{C}$ for $10 \mathrm{~min}$. Although the authors have used a higher temperature, it was not sufficient to degrade chlorophylls, and it may be related to the duration time of PHWE process (10 min). Moreover, as already mentioned, this process at high temperatures changes the water properties, which are closer to the properties of the compound of interest (Bursać Kovačević et al., 2018; Teo, Tan, Yong, Hew, \& Ong, 2010). Generally, the water viscosity reduces with an increase of temperature enhancing the solute solubility, and it can also assist with breaking of analyte-matrix bonds facilitating the diffusion of these analytes (Bursać Kovačević et al., 2018).

Some researches applied the PHWE to extract BCs from grape byproducts. Vergara-Salinas et al. (2013) applied this technique to grape pomace, and they also achieved high recovery rates of BCs such as proanthocyanidin, when high temperatures were applied during this process. The authors concluded that both temperature and time are critical to anthocyanins stability. Maximum temperatures at $100{ }^{\circ} \mathrm{C}$ during short times exposure (5 $\mathrm{min}$ ) are enough to obtain higher amounts of anthocyanins. Nevertheless, temperatures higher than $100{ }^{\circ} \mathrm{C}$ and long time exposure could degrade this compound. The anthocyanins degradation can be caused by the pyrilium ring of anthocyanins opening by the increase of temperature (greater than $100{ }^{\circ} \mathrm{C}$ ), or by its sugar moiety cleavage to form a more labile anthocyanin aglycon (Vergara-Salinas et al., 2013).

The same authors (Vergara-Salinas, Vergara, Altamirano, Gonzalez, \& Pérez-Correa, 2015) in other study detected the presence of phenolic compounds, such as $(+)$-catechin, (-)-epicatechin, kaempferol and myricetin, and hydroxymethylfurfural (5-HMF) from grape pomace. Furthermore, they found that the increase of temperature changes the extraction of the phenolic compounds. At $100{ }^{\circ} \mathrm{C}$ favors the (+)-catechin, kaempferol and myricetin extraction, while the (-)-epicatechin content decrease. The differences could be explained by the impact of temperature on phenols stability (as explained earlier). Besides, the best results to (-)-epicatechin extraction at higher temperatures $\left(200{ }^{\circ} \mathrm{C}\right)$ could be explained by the breakdown of tannin bonds, which release the subunits.

The disadvantage of the method is the water corrosion at higher temperatures and pressures. Thus, the material should be appropriate to prevent it.

The PHWE is very similar to the SFE, only introduces some alterations. The PHWE needs more time to extract than SFE due to the different resistances usages, which water needs throughout (Ameer et al., 2017). This method can be applied to other than food matrices (e.g chemical mixtures) and obtain a wide variety of compounds (Plaza \& Marina, 2019), while SFE could be limited to the food matrix due to the higher pressures used and its unimpressive efficiency to use in high capacity industrial chemical processes.

Comparing this method with one previously described, MAE, the PHWE does not require a secondary "clean-up" methodology; this can be intrinsic in the process (Ameer et al., 2017; Plaza \& Marina, 2019). Besides that, to recover compounds, the PHWE requires less time of extraction than the conventional method, as the Soxhlet. Nevertheless, it spends more extraction time compared with MAE, but is less expensive. 


\subsection{Pulsed electric field}

The application of emerging, novel processing techniques such as pulsed electric energy can be used to quality improvements and consumer benefits (Barba et al., 2016; Cholet et al., 2014; Comuzzo et al., 2020).

Although pulsed electric energy was discovered in 1791 by Luigi Galvani, only two centuries later, the effect of electroporation was established, and its ability to potentiate the extraction of anthocyanins from grape by electrical breakage of cellular membranes was observed. Nowadays, this assisted processing includes a pulsed electric field (PEF), pulsed ohmic heating $(\mathrm{OH})$, and high voltage electrical discharge techniques (Maroun et al., 2017; Rocha et al., 2018).

PEF technology is a non-thermal method of food preservation that involves the discharge of high voltage electric pulses to liquid or semisolid foods placed between two electrodes for a few to several hundred microseconds. This technique allows the extraction of intracellular compounds by the formation of pores in the membrane (electroporation) without affecting the structure of cell walls noticeably. The extraction efficiency depends on parameters such as pulse duration (pulse width), number of pulses, and pauses between pulses (Baiano, 2014). In skins and pulp, the energy input is lower in PEF when compared with conventional methods (mechanical or enzymatic), representing 1 to 15 and 20 to $100 \mathrm{KJ} / \mathrm{Kg}$, respectively, which demonstrate to be an environmental friendly technology (Rocha et al., 2018).

PEF technology is advantageous when compared with traditional thermal treatments because it causes microbial inactivation with minimal detrimental effect on food quality attributes (maintaining original color, flavor, texture, and nutritional value of the unprocessed food). Also, it avoids or significantly reduces detrimental changes in the sensory and physical properties of foods (Baiano, 2014; Barba et al., 2016; Comuzzo et al., 2020).This technology has been used by several food industries to scale-up the extraction process and the pre-treatment of food matrices (Barba et al., 2016).

Corrales, Toepfl, Butz, Knorr, \& Tauscher, (2008), used PEF to extract anthocyanins from grape by-products. They reported that after 1 $\mathrm{h}$ extraction (performed in a water bath at $70{ }^{\circ} \mathrm{C}$ during $1 \mathrm{~h}$ ), the total phenolic content of samples was $50 \%$ higher than the control samples. The application of novel technologies also increased the antioxidant activity of the extracts being the extractions carried out with PEF fourfold higher than the control extraction. Besides, they also observed that anthocyanin mono-glucosides extraction was higher when PEF was applied, while acylated anthocyanin was better extracted by high hydrostatic pressure. The PEF application induces the acylated glucoside anthocyanins trapping inside the matrix or establish hydrogen bonds with cell wall polysaccharides. The solid/liquid ratio (1:20) and the holding times used is very important to obtain the highest yields of anthocyanins extraction with PEF. Their stability and chemical structure depend on the ratio anthocyanins: solution, $\mathrm{pH}$ value, the $\mathrm{OH}-$ and $\mathrm{OCH}_{2}$ - groups at position $\mathrm{R}_{1}$ in $\mathrm{C}_{3}$, and $\mathrm{R}_{2}$ in $\mathrm{C}_{5}$, of $\mathrm{B}$ ring and the sugar moieties or phenolic acyl groups of the $\mathrm{C}$ ring (Fig. 5). Also, $\mathrm{PEF}$ changes $\mathrm{pH}$ values to $\mathrm{pH}<4$ allowed for better extraction of acylated anthocyanins due to their stability at this $\mathrm{pH}$ value.

This technique was also used to extract total tannins and polysaccharides by Cholet et al. (2014). They applied two PEF treatment parameters, and firstly, they use a voltage of $4 \mathrm{kV} / \mathrm{cm}$ with a duration of $1 \mathrm{~ms}$ and, secondly, $0.7 \mathrm{kV} / \mathrm{cm}$ with a duration of $200 \mathrm{~ms}$. The authors verified that the first treatment has a lower impact on phytochemicals than the second treatment. These results obtained by authors indicate that the duration of PEF treatment has a high impact on the organization of the cell wall of the skin and causes skin tannins depolymerization. It has also been observed that the highest applied electric field modified the vacuolar tannins. Also, while the highest PEF energy can induce damage on parietal and cell walls tannins of grape skins, the highest PEF strength modified the vacuolar tannins leading to the increase of the degree of permeabilization of the cellular membrane and allowing the release of intracellular compounds. Higher yields of extraction were obtained by Comuzzo et al. (2020) when compare the effects of PEF as pre-treatment (applying energy of 2, 10, and $20 \mathrm{~kJ}$. Kg) extraction enzymes on color and polyphenols during skin maceration from red grapes. The 10 and $20 \mathrm{~kJ} . \mathrm{Kg}$ energies exhibited higher phenolic compounds than $2 \mathrm{~kJ} . \mathrm{Kg}$ and the enzymatic extraction. The results suggest that the increase in PEF intensity create large pores in the cell membrane, which may allow the release of more complex phenolic compounds and protecting others (e.g. anthocyanins) towards oxidation.

\subsection{Ohmic heating}

$\mathrm{OH}$ is an environmentally friendlier and more efficient thermal technology than traditional methods currently used in food processing; in $\mathrm{OH}$, an electric current is passed directly through materials having electrical resistance, generating heat and increasing the instantaneous and homogeneous temperature inside the product (Coelho et al., 2019; Pereira et al., 2016). This technology has an energy efficiency of over $90 \%$ and, when compared to the conventional thermal method, which is less efficient, can achieve energy savings of up to $70 \%$ (Rocha et al., 2018).

By applying $\mathrm{OH}$, some $\mathrm{BCs}$ are not degraded as in traditional heat treatments. This method is efficient in inactivating enzymes and microorganisms. Nevertheless, few studies are reporting its impact on structural changes in food or BCs present in by-products, which may compromise safety and bioavailability. Moreover, it allows more efficient extraction of BCs from organic by-products minimizing extraction time, reducing organic solvent consumption, and maintaining recovery of compounds of interest (Maroun et al., 2017).

The $\mathrm{OH}$ method advantages compared to conventional heating include the more uniform and faster heating, higher yield, and higher retention of nutritional value of food (Rodrigues et al., 2015). It is mainly due to its ability to heat materials rapidly and uniformly, leading to a less aggressive thermal treatment. Nevertheless, their effects on plant tissues are scarcely known. In grape skins, tissue damage was observed, maybe induced by electrical breakdown, or an electroporation mechanism. Furthermore, at low frequencies, cell walls build up charges and form pores altering membrane permeability (Kaur, Gul, \& Singh, 2016; Pereira, Teixeira, \& Vicente, 2011, 2020).

An example is the extraction of polyphenols that was increased in red grape pomace by the application of $\mathrm{OH}$. It is due to an alteration in cell membranes and, consequently, an acceleration of the polyphenols diffusion kinetics. El Darra, Grimi, Vorobiev, Louka, and Maroun (2013) obtained a $36 \%$ higher extraction yield in pretreated extracts of grape pomace with $\mathrm{OH}(400 \mathrm{~V} / \mathrm{cm})$ compared to the conventional method. On the other hand, literature has shown degradation of heat-sensitive compounds, as anthocyanins compounds. As previously mentioned, the anthocyanins are very unstable, and their degradation is also dependent on the voltage applied (Maroun et al., 2017).

Ohmic Heating applied at moderate electric fields have shown the potential to enhance extraction of anthocyanins and other BCs (phenolic compounds, including anthocyanins) from winemaking residues such as grape skins and seeds (results not published), suggesting that $\mathrm{OH}$ is a promising industrial method for BCs extraction from grape by-products.

\subsection{High voltage electric discharge (HVED)}

HVED method is based on the treatment of liquid food placed in a chamber between a needle electrode and a plated grounded electrode using short electric pulses (typically, $40-60 \mathrm{kV} / \mathrm{cm}, 2-5 \mu \mathrm{s}$ ). The most promising application is for enhancing the extraction of oil from oilseeds (Barba et al., 2016).

The method is optimized by controlling the number of pulses, $\mathrm{pH}$, water/press-cake ratio, and temperature.

Boussetta, Lanoisellé, Bedel-Cloutour, and Vorobiev (2009) showed that the HVED method is a promising technique for the extraction of 
polyphenols from grape pomace (composed of stems seeds and skins). This method was applied to the pomace samples mixed with distilled water and at temperatures ranging from 20 to $60^{\circ} \mathrm{C}$ using 80 successive discharges $(40 \mathrm{kV}$, pulse repetition rate $0.5 \mathrm{~Hz})$. The HVED treatment allowed an increase of the final yields of solutes with a decrease of time of diffusion. Nevertheless, the pilot-scale of HVED-assisted extraction spent a high volume of solvent and required higher treatment energies. Afterward, Boussetta et al. (2013) compared this technology (HVED 40 $\mathrm{kV})$ with PEF $(8-20 \mathrm{kV} / \mathrm{cm}, 0-20 \mu \mathrm{s})$ and grinding (180 W, $40 \mathrm{~s}$ ) on polyphenols extraction from grape seeds. The authors showed an extraction efficiency by HVED and grinding, with subsequent ethanol extraction, higher than PEF. Rajha, Boussetta, Louka, Maroun, and Vorobiev (2015) also compare the effects of alternative physical treatments (HVED, PEF, and ultrasound) on dead-end ultrafiltration of vine shoot. They analyzed the cellular damage that was higher for grinding and followed by HVED ( $360 \mathrm{~kJ} / \mathrm{kg}$ and $\mathrm{Z}=1 ;(242 \mathrm{~kJ} / \mathrm{kg}$ and $\mathrm{Z}=0.71$, respectively) showing proteins concentrations above $0.097 \mathrm{mg} / \mathrm{mL}$ to grinding and $0.082 \mathrm{mg} / \mathrm{mL}$ to HVED. Total phenolic concentrations were 0.4 and $0.3 \mathrm{mg} / \mathrm{mL}$ for grinding and HVED, respectively). These results were obtained because authors with both treatments caused cell disintegration, improving the extraction of the intracellular compounds. In addition, higher yields of extraction could be obtained during HVED application due to the electrical breakdown followed by different phenomena, namely high-amplitude pressure shock waves, bubbles cavitation, creation of liquid turbulence, and production of active species leading to particle fragmentation and cell rupture of tissues and consequently.

\section{Applications}

In this review, we focus on emerging extraction processes and their effects on the recovery of compounds. It is noteworthy that the period between by-product production and its valorisation, in conjunction with recover procedures, have a direct impact on phytochemicals and, therefore, on the potential of BCs. This compound recovery strategy is crucial for the valorisation of this by-product, to ensure a safe and highquality compounds recovery, in a circular economy context. The BCs from grape by-products have been reported in the literature applied to a large number of food, cosmetic, and pharmaceutical applications since they act as multipurpose ingredients or additives.

\subsection{Food applications}

As food applications, these BCs, due to their multifunctional characteristics, could be used to develop novel and functional foods. The dietary antioxidants recovered from grape by-products, such as polyphenols (e.g., phenolic acids, flavonoids), and vitamin E could be used as fortification of meat and bakery products, oxidative protection in olive and vegetable oils (Galanakis, Tsatalas, \& Galanakis, 2018b) and enhancement of color stability in meat products (Galanakis, 2018; Kalli et al., 2018), in particular of cooked beef and pork patties (Rojas \& Brewer, 2008). Rojas and Brewer (2008), reported increased stability in oxidative and color of raw beef and pork patties during 4 months stored frozen in a vacuum packaging. Also, extracts from grape pomace and grape seeds rich in antioxidants, polyphenols (phenolic acids, namely p-coumaric, cinnamic, caffeic, ferulic, gallic, sinapic, chlorogenic, protocatechuic, syringic and vanillic acids as well as flavonoids), vitamin E, were able to extend the lamb meat shelf-life after a week of storage (Guerra-Rivas et al., 2016). Phenols reduced lipid peroxidation and meat discoloration (Guerra-Rivas et al., 2016) by hydrogen donating and sequentially quenching of radicals (Galanakis, 2018). Both phenols and vitamin E are also used as antimicrobials (e.g. against Bacillus subtilis, Staphylococcus aureus, Pseudomonas aeruginosa and Escherichia coli), retarding rancidity and enhancing the shelf life of bakery products, as pastry and sugar-snap cookies and crackers (Galanakis, Tsatalas, \& Galanakis, 2018a; 2018b). Also, phenols recovered from Merlot grape seed flour were used to enriched noodles, cereal bars and pancakes, with high antioxidant activity and consumer acceptance. The dietary fiber was used as a supplement and with a possible prebiotic function (Kalli et al., 2018).

\subsection{Cosmetics and sunscreen industry}

The term cosmeceutical is resulting from the combination of "cosmetic" and "pharmaceutical," suggesting that the products have active components. These products take components with medical or drug-like benefits and are developed to change positive physical outcomes at the cellular level in addition to enhancing the surface's appearance. The fundamental premise is that new BCs from natural sources are safer and equally or more efficacious than synthetic ones. These compounds should have extremely efficient and stable attributes for therapeutic usage with reduced possible toxicity. Recently, agro-food by-products have been demonstrated as rich sources of structurally diverse, biologically active compounds with considerable cosmeceutical potential (Dzah, Duan, Zhang, Serwah Boateng, \& Ma, 2020; Galanakis, 2018b).

Presently, there are considerable research activities in progress regarding developing and characterization of extract full formulation to concurrently accomplish several goals, e.g., anti-inflammatory and antiaging effects. The main BCs used are polyphenols, flavonoids and carotenoids. These compounds maintain both antioxidant and UV protection. For example, quercetin improves the photostability of two conventional UVA (320-400 nm) and UVB (290-320 nm) filters (Galanakis et al., 2018a; 2018b).

It should be noted that antioxidants not only prevent against reactive species as increase UV absorption of sunscreen agents (Galanakis et al., 2018a).

Other compounds, such as vitamin $\mathrm{C}$ and vitamin $\mathrm{E}$ and ubiquinone, coenzyme Q10, showed photostability of avobenzone, reducing the skin damage induced by UV (Afonso et al., 2014). Galanakis et al. (2018b) obtained more active UV filters in a broader region of UVB and UVA to olive phenols from mill wastewater than to ascorbic acid and $\alpha$-tocopherol. The authors showed that these by-products are effective against UV radiation, with great potential to be used in sunscreens and cosmetics. Nevertheless, the polyphenols used in cosmetic is accomplishing with some problems, such as solubility in water which compromises its diffusion through the skin (Galanakis et al., 2018a), chemical instability, and low bioavailability (Kalli et al., 2018). Thus, they can be removed with seawater immersion and compromise its effectiveness. In this sense, studies have been carried out to overcome the phenols' water solubility (Galanakis et al., 2018a; 2018b). They have shown that encapsulation can increase the bioavailability and protect the degradation of the BCs (Galanakis et al., 2018a; (Kalli et al., 2018). Galanakis et al. (2018a) showed that the silica particles could increase the water-resistance of olive phenols' cosmetic formulations. If, during the extraction processes of agro-industrial by-products silica is also recovered, we are facing a sustainable alternative that fits into the current circular economy context. Thus the utilization of the by-products allows the cosmetic industry (a) to formulate more economical and sustainable skin products, (b) to obtain purer compounds to formulate clean-beauty, and finally (c) to adopt the REACH directives regarding the advisable solvents (Galanakis et al., 2018b).

\section{Industry scale-up}

The technologies presented before, are considered environmentally friendly compared to conventional methods, indicating a current alternative towards sustainable industrial production (Del Borghi, Moreschi, \& Gallo, 2020). On the other hand, most of these processes have only been tested at the laboratory scale, and additional studies are needed for scaling up these procedures. Depending on the technology involved, it may make more sense to scale-up the recovery processes for BCs at the 
industrial level. For example, concerning solid-liquid extraction, this scale-up process is minimal, not only because it uses an enormous amount of solvents, but also has high energy costs (Del Borghi et al., 2020). As alternatives, PHWE, MAE, PEF, OH extractions, and the use of supercritical fluids have also been investigated for the recovery at scale-up level from grape by-products (Chizoba Ekezie, Sun, Han, \& Cheng, 2017; Cravotto et al., 2018; Elliott, Schmidt, Hart, \& Billing, 2017; Guo, Sun, Cheng, \& Han, 2017). Regarding the MAE, although increasing the extraction time increases the yield, it is minimal. Besides, when looking at an industrial scale, a higher number of samples are instilled as well as the fact that it is a stepwise process, other requirements such as increasing solvents and a higher number of microwave systems are necessary (Chizoba Ekezie, Sun, Han, \& Cheng, 2017; Ekezie, Sun, \& Cheng, 2017). Therefore, MAE is not an advisable method for industrial purposes. The PHWE, PEF and $\mathrm{OH}$ technologies, in general, needs lower energy consumption compared with conventional pretreatment methods and extraction technologies. However, its industrialization implies working with much higher processing volumes when compared to the laboratory scale. This industrialization presents some challenges, such as the need to work with larger treatment chambers or fluxes, with larger electrode surface areas and electrode gap (Rocha et al., 2018).

Consequently, high energy capacity increased output voltage, but higher pulse frequency is required. But these processes could use a renewable source of energy (e.g., hydroelectric power) to produce electricity. Which, together with the current output with defined shape and pulse/wave frequency, still represents a challenge (Rocha et al., 2018). However, the increase in the application of MEF and PEF systems in the food industry contributes to its reliability increase and cost reduction during the process. Also, the investment in the development and innovation by partnerships with universities and companies has contributed to the optimization, not only in the materials used in the projects of electrical treatment chambers but also in the continuous operation mode, which has contributed to the investigation of industrial viability (Rocha et al., 2018).

It should be noted that high energy efficiency results in an overall reduction in energy consumption. Associated with the increase in the $\mathrm{BCs}$ recovery rate and some cases the solvents reduction, or even its elimination, these technologies allow to reduce the use of nonrenewable energies, increasing the value-added of the by-products and contributing to a more sustainable world within the scope of a circular economy.

\section{Conclusion and future remarks}

Grape pomace represents the main fraction of solid grape byproducts and are a good source of BCs, such as total dietary fiber (almost 60\%), polyphenols (6-15\%) (mainly flavonols: quercetin, kaempferol, and myricetin; flavan-3-ols: catechin and epicatechin; tannins and anthocyanins: and proteins (5-12\%). Polyphenols are generally responsible for sensorial properties but also for health benefits, namely, antimicrobial, anti-inflammatory, anti-cancer, and preventing cardiovascular diseases. In this way, the application of emerging food technologies has been useful to minimize the adverse effects of conventional techniques, facilitate the production of valuable natural products, which guarantee food sustainability and meet consumer demands and to reduce grape by-products. Also, both $\mathrm{OH}$ and SFE have higher potential due to their time-efficiency, quickly to scale up to the industrial level, and both technologies could use directly ethanol of a winemaking industry, heat, electricity already available, and $\mathrm{CO}_{2}$, avoiding logistics costs. Furthermore, both techniques allow a selective extraction, and they have been successfully applied for different BCs, including anthocyanins by $\mathrm{OH}$ and fibers by SFE.

Some technologies comparisons, such as $\mathrm{OH}$, microwave, and solvent extraction, for anthocyanins extraction from grape by-products, have not been studied before. Furthermore, the combination of SLE with enzymes and new technologies can significantly enhance the BCs recovery. For instance, they can break the bound polyphenols to proteins and polysaccharides, e.g., hemicellulose, cellulose, and pectin, in the food matrix. Nevertheless, there are a lack of information about the recovery and reuse of products obtained after the application of enzymes, ionic liquids together with green technologies presented before. For this reason, feasibility for BCs recovery must be deeply studied in the future to understand the benefits of this type of solvents and technologies and their toxicity, stability and bioactivity This study is of high relevance since an optimal recovery of fibers, and other BCs from grape by-products brings the high potential for product development according to current industry and consumer demands based on a circular economy system.

\section{Declaration of competing interest}

The authors declare no conflict of interests.

\section{Acknowledgments}

This work was supported by Portuguese funds from Foundation for Science and Technology (FCT) through project MULTIBIOREFINERY SAICTPAC/0040/2015 (POCI-01-0145-FEDER-016403). Furthermore, the authors would also acknowledge the scientific collaboration of CBQF under the FCT project UID/Multi/50016/2019, UIDB/04469/2020, and BioTecNorte operation (NORTE-01-0145-FEDER-000004) funded by the European Regional Development Fund under the scope of Norte2020 Programa Operacional Regional do Norte. The author Marta Coelho would like to acknowledge FCT for your PhD grant with the reference SFRH/BD/111884/2015.

\section{References}

Abdrabba, S., \& Hussein, S. (2015). Chemical composition of pulp, seed and peel of red grape from Libya. Global Journal of Scientific Researches, 3(2), 6-11. https://doi.org/ 10.1016/S0376-7388(00)81532-X

Afonso, S., Horita, K., Sousa E Silva, J. P., Almeida, I. F., Amaral, M. H., Lobão, P. A., et al. (2014). Photodegradation of avobenzone: Stabilization effect of antioxidants. Journal of Photochemistry and Photobiology B: Biology. https://doi.org/10.1016/j. jphotobiol.2014.07.004

Ameer, K., Shahbaz, H. M., \& Kwon, J. H. (2017). Green extraction methods for polyphenols from plant matrices and their byproducts: A review. Comprehensive Reviews in Food Science and Food Safety, 16(2), 295-315. https://doi.org/10.1111, 1541-4337.12253

Ananey-Obiri, D., Matthews, L., Azahrani, M. H., Ibrahim, S. A., Galanakis, C. M., \& Tahergorabi, R. (2018). Application of protein-based edible coatings for fat uptake reduction in deep-fat fried foods with an emphasis on muscle food proteins. Trends in food science and technology. https://doi.org/10.1016/j.tifs.2018.08.012

Apolinar-Valiente, R., Romero-Cascales, I., Williams, P., Gómez-Plaza, E., LópezRoca, J. M., Ros-García, J. M., et al. (2015). Oligosaccharides of cabernet sauvignon, syrah and monastrell red wines. Food Chemistry, 179, 311-317. https://doi.org/ 10.1016/j.foodchem.2015.01.139

Arranz, S., Medina-Remn, A. M. R., \& Estruch, R. (2012). Effects of dietary fiber intake on cardiovascular risk factors. In Recent advances in cardiovascular risk factors. https:// doi.org/10.5772/32271

Atanacković Krstonošić, M., Barba, F. J., Bursać, M., Drago, S. R., Fissore, E. N., Galanakis, C. M., \& xv-xvi. (2017). List of contributors BT - Nutraceutical and functional food components. Academic Press. https://doi.org/10.1016/B978-0-12805257-0.00018-1

Baiano, A. (2014). Recovery of biomolecules from food wastes-a review. Molecules (Basel, Switzerland), 19(9), 14821-14842. https://doi.org/10.3390/molecules190914821

Barba, F. J., Galanakis, C. M., Esteve, M. J., Frigola, A., \& Vorobiev, E. (2015b). Potential use of pulsed electric technologies and ultrasounds to improve the recovery of highadded value compounds from blackberries. Journal of Food Engineering. https://doi. org/10.1016/j.jfoodeng.2015.02.001

Barba, F. J., Zhu, Z., Koubaa, M., Sant'Ana, A. S., \& Orlien, V. (2016). Green alternative methods for the extraction of antioxidant bioactive compounds from winery wastes and by-products: A review. In Trends in food science and technology (Vol. 49, pp. 96-109). https://doi.org/10.1016/j.tifs.2016.01.006

Benucci, I., Río Segade, S., Cerreti, M., Giacosa, S., Paissoni, M. A., Liburdi, K., et al. (2017). Application of enzyme preparations for extraction of berry skin phenolics in withered winegrapes. Food Chemistry. https://doi.org/10.1016/j. foodchem.2017.06.003

Beres, C., Simas-Tosin, F. F., Cabezudo, I., Freitas, S. P., Iacomini, M., Mellinger-Silva, C., et al. (2016). Antioxidant dietary fibre recovery from Brazilian Pinot noir grape pomace. Food Chemistry. https://doi.org/10.1016/j.foodchem.2016.01.039 
Boussetta, N., Grimi, N., \& Vorobiev, E. (2015). Pulsed electrical technologies assisted polyphenols extraction from agricultural plants and bioresources: A review. Int $J$ Food Process Technol, 2, 1-10.

Boussetta, N., Lanoisellé, J. L., Bedel-Cloutour, C., \& Vorobiev, E. (2009). Extraction of soluble matter from grape pomace by high voltage electrical discharges for polyphenol recovery: Effect of sulphur dioxide and thermal treatments. Journal of Food Engineering, 95(1), 192-198. https://doi.org/10.1016/j.jfoodeng.2009.04.030

Burin, V. M., Ferreira-Lima, N. E., Panceri, C. P., \& Bordignon-Luiz, M. T. (2014). Bioactive compounds and antioxidant activity of Vitis vinifera and Vitis labrusca grapes: Evaluation of different extraction methods. Microchemical Journal. https ://doi.org/10.1016/j.microc.2013.12.014.

Bursać Kovačević, D., Barba, F. J., Granato, D., Galanakis, C. M., Herceg, Z., DragovićUzelac, V., et al. (2018). Pressurized hot water extraction (PHWE) for the green recovery of bioactive compounds and steviol glycosides from Stevia rebaudiana Bertoni leaves. Food Chemistry. https://doi.org/10.1016/j.foodchem.2018.01.192

Cádiz-Gurrea, M. D. L. L., Borrás-Linares, I., Lozano-Sánchez, J., Joven, J., FernándezArroyo, S., \& Segura-Carretero, A. (2017). Cocoa and grape seed byproducts as a source of antioxidant and anti-inflammatory proanthocyanidins. International Journal of Molecular Sciences, 18(2), 376. https://doi.org/10.3390/ijms18020376

Chemat, F., Abert Vian, M., Fabiano-Tixier, A. S., Nutrizio, M., Režek Jambrak, A., Munekata, P. E. S., et al. (2020). A review of sustainable and intensified techniques for extraction of food and natural products. In Green chemistry. https://doi.org/ $10.1039 / \mathrm{c} 9 \mathrm{gc} 03878 \mathrm{~g}$

Chizoba Ekezie, F. G., Sun, D. W., Han, Z., \& Cheng, J. H. (2017). Microwave-assisted food processing technologies for enhancing product quality and process efficiency: A review of recent developments. In Trends in food science and technology. https://doi. org/10.1016/j.tifs.2017.05.014

Cholet, C., Delsart, C., Petrel, M., Gontier, E., Grimi, N., L'Hyvernay, A., et al. (2014). Structural and biochemical changes induced by pulsed electric field treatments on cabernet sauvignon grape berry skins: Impact on cell wall total tannins and polysaccharides. Journal of Agricultural and Food Chemistry, 62(13), 2925-2934. https://doi.org/10.1021/jf404804d

Coelho, M., Pereira, R., Rodrigues, A. S., Teixeira, J. A., \& Pintado, M. E. (2019). Extraction of tomato by-products' bioactive compounds using ohmic technology. Food and Bioproducts Processing, 117, 329-339. https://doi.org/10.1016/j.fbp.201 9.08.005.

Coman, V., Teleky, B. E., Mitrea, L., Martău, G. A., Szabo, K., Călinoiu, L. F., et al. (2019). Bioactive potential of fruit and vegetable wastes. In Advances in food and nutrition research. https://doi.org/10.1016/bs.afnr.2019.07.001

Comuzzo, P., Voce, S., Grazioli, C., Tubaro, F., Marconi, M., Zanella, G., et al. (2020). Pulsed electric field processing of red grapes (cv. Rondinella): Modifications of phenolic fraction and effects on wine evolution. Foods, 9(4), 414. https://doi.org/ 10.3390/foods 9040414

Corrales, M., Toepfl, S., Butz, P., Knorr, D., \& Tauscher, B. (2008). Extraction of anthocyanins from grape by-products assisted by ultrasonics, high hydrostatic pressure or pulsed electric fields: A comparison. Innovative Food Science \& Emerging Technologies. https://doi.org/10.1016/j.ifset.2007.06.002.

Cravotto, G., Mariatti, F., Gunjevic, V., Secondo, M., Villa, M., Parolin, J., et al. (2018) Pilot scale cavitational reactors and other enabling technologies to design the industrial recovery of polyphenols from agro-food by-products, a technical and economical overview. In Foods. https://doi.org/10.3390/foods7090130

Del Borghi, A., Moreschi, L., \& Gallo, M. (2020). In E. Galanakis (Ed.), 3 - life cycle assessment in the food industry (pp. 63-118). Academic Press. https://doi.org/ 10.1016/B978-0-12-816449-5.00003-5. C. B. T.-T. I. of F. I.

Deng, Q., Zinoviadou, K. G., Galanakis, C. M., Orlien, V., Grimi, N., Vorobiev, E., et al (2015). The effects of conventional and non-conventional processing on glucosinolates and its derived forms, isothiocyanates: Extraction, degradation, and applications. In Food engineering reviews https://doi.org/10.1007/s12393-014-9104. 9

Dimić, I., Teslic, N., Putnik, P., Bursać Kovačević, D., Zekovic, Z., Šojić, B., et al. (2020). Innovative and conventional valorizations of grape seeds from winery by-products as sustainable source of lipophilic antioxidants. Antioxidants, 9, 568. https://doi.org/ 10.3390/antiox9070568

Dzah, C. S., Duan, Y., Zhang, H., Serwah Boateng, N. A., \& Ma, H. (2020). Latest developments in polyphenol recovery and purification from plant by-products: A review. In Trends in food science and technology. https://doi.org/10.1016/j. tifs.2020.03.003

Ekezie, F.-G. C., Sun, D.-W., \& Cheng, J.-H. (2017). Acceleration of microwave-assisted extraction processes of food components by integrating technologies and applying emerging solvents: A review of latest developments. Trends in Food Science \& Technology, 67, 160-172. https://doi.org/10.1016/j.tifs.2017.06.006.

El Darra, N., Grimi, N., Vorobiev, E., Louka, N., \& Maroun, R. (2013). Extraction of polyphenols from red grape pomace assisted by pulsed ohmic heating. Food and Bioprocess Technology, 6(5), 1281-1289. https://doi.org/10.1007/s11947-012-0869.

Elliott, D. C., Schmidt, A. J., Hart, T. R., \& Billing, J. M. (2017). Conversion of a wet waste feedstock to biocrude by hydrothermal processing in a continuous-flow reactor: Grape pomace. Biomass conversion and biorefinery. https://doi.org/10.100 7/s13399-017-0264-8.

FAO. (2019). FAO. 2019: The state of food and agriculture 2019, moving forward on food loss and waster reduction. Routledge handbook of religion and ecology. https://doi.org/ $10.4324 / 9781315764788$

Fernández, K., Vega, M., \& Aspé, E. (2015). An enzymatic extraction of proanthocyanidins from País grape seeds and skins. Food Chemistry. https://doi.org/ 10.1016/j.foodchem.2014.07.021
Galanakis, C. M. (2012). Recovery of high added-value components from food wastes: Conventional, emerging technologies and commercialized applications. Trends in food science and technology. https://doi.org/10.1016/j.tifs.2012.03.003

Galanakis, C. M. (2013). Emerging technologies for the production of nutraceuticals from agricultural by-products: A viewpoint of opportunities and challenges. Food and Bioproducts Processing, 91(4), 575-579. http://doi.org/10.1016/j.fbp.2013.01.004.

Galanakis, C. M. (2014). Food waste recovery. Igarss, (Issue 1)https://doi.org/10.1007/ s13398-014-0173-7.2, 2014.

Galanakis, C. M. (2015a). Food waste recovery: Processing technologies and industrial techniques. In Food waste recovery: Processing technologies and industrial techniques. https://doi.org/10.1016/C2013-0-16046-1

Galanakis, C. M. (2015b). Separation of functional macromolecules and micromolecules: From ultrafiltration to the border of nanofiltration. Trends in food science and technology. https://doi.org/10.1016/j.tifs.2014.11.005

Galanakis, C. M. (2018). Phenols recovered from olive mill wastewater as additives in meat products. Trends in food science and technology. https://doi.org/10.1016/j. tifs.2018.07.010

Galanakis, C. M. (2020). The food systems in the era of the coronavirus (CoVID-19) pandemic crisis. Foods. https://doi.org/10.3390/foods9040523

Galanakis, C. M., Tsatalas, P., Charalambous, Z., \& Galanakis, I. M. (2018). Polyphenols recovered from olive mill wastewater as natural preservatives in extra virgin olive oils and refined olive kernel oils. Environmental Technology and Innovation. https:// doi.org/10.1016/j.eti.2018.01.012

Galanakis, C. M., Tsatalas, P., \& Galanakis, I. M. (2018a). Implementation of phenols recovered from olive mill wastewater as UV booster in cosmetics. Industrial Crops and Products. https://doi.org/10.1016/j.indcrop.2017.09.058

Galanakis, C. M., Tsatalas, P., \& Galanakis, I. M. (2018b). Phenols from olive mill wastewater and other natural antioxidants as UV filters in sunscreens. Environmental Technology and Innovation. https://doi.org/10.1016/j.eti.2017.12.002

García-Lomillo, J., González-SanJosé, M. L., Del Pino-García, R., Rivero-Pérez, M. D., \& Muñiz-Rodríguez, P. (2014). Antioxidant and antimicrobial properties of wine byproducts and their potential uses in the food industry. Journal of Agricultural and Food Chemistry, 62(52), 12595-12602. https://doi.org/10.1021/jf5042678

Ghafoor, K., Park, J., \& Choi, Y. H. (2010). Optimization of supercritical fluid extraction of bioactive compounds from grape (Vitis labrusca B.) peel by using response surface methodology. Innovative Food Science \& Emerging Technologies, 11(3), 485-490. https://doi.org/10.1016/j.ifset.2010.01.013

Gligor, O., Mocan, A., Moldovan, C., Locatelli, M., Crișan, G., \& Ferreira, I. C. F. R. (2019). Enzyme-assisted extractions of polyphenols - a comprehensive review. In Trends in food science and technology. https://doi.org/10.1016/j.tifs.2019.03.029

Gómez-García, R., Campos, D. A., Aguilar, C. N., Madureira, A. R., \& Pintado, M. (2020). Valorization of melon fruit (cucumis melo L.) by-products: Phytochemical and biofunctional properties with emphasis on recent trends and advances. Trends in food science \& technology. https://doi.org/10.1016/j.tifs.2020.03.033

González-Centeno, M. R., Jourdes, M., Femenia, A., Simal, S., Rosselló, C., \& Teissedre, P. L. (2013). Characterization of polyphenols and antioxidant potential of white grape pomace byproducts (Vitis vinifera L.). Journal of Agricultural and Food Chemistry, 61(47), 11579-11587. https://doi.org/10.1021/jf403168k

Guerra-Rivas, C., Vieira, C., Rubio, B., Martínez, B., Gallardo, B., Mantecón, A. R., . Manso, T. (2016). Effects of grape pomace in growing lamb diets compared with vitamin E and grape seed extract on meat shelf life. Meat Science. https://doi.org/10. 1016/j.meatsci.2016.02.022.

Gullón, P., Gullón, B., Romaní, A., Rocchetti, G., \& Lorenzo, J. M. (2020). Smart advanced solvents for bioactive compounds recovery from agri-food by-products: A review. Trends in food science and technology. https://doi.org/10.1016/j. tifs.2020.05.007

Guo, Q., Sun, D. W., Cheng, J. H., \& Han, Z. (2017). Microwave processing techniques and their recent applications in the food industry. Trends in food science and technology. https://doi.org/10.1016/j.tifs.2017.07.007

Hanušovský, O., Gálik, B., Bíro, D., Šimko, M., Juráček, M., Rolinec, M., et al. (2020). The nutritional potential of grape by-products from the area of Slovakia and Austria. Emirates Journal of Food and Agriculture. https://doi.org/10.9755/ejfa.2020.v32. i1.2051

Hogervorst, J. C., Miljić, U., \& Puškaš, V. (2017). 5 - extraction of bioactive compounds from grape processing by-products A2 - Galanakis, charis M. In Handbook of grape processing by-products (pp. 105-135). https://doi.org/10.1016/B978-0-12-8098707.00005-3.

Ianni, \& Martino. (2020). Dietary grape pomace supplementation in dairy cows: Effect on nutritional quality of milk and its derived dairy products. Foods, 9(2), 168. https:// doi.org/10.3390/foods9020168

Kafantaris, I., Kotsampasi, B., Christodoulou, V., Makri, S., Stagos, D., Gerasopoulos, K., et al. (2018). Effects of dietary grape pomace supplementation on performance, carcass traits and meat quality of lambs. Vivo. https://doi.org/10.21873/ invivo.11311

Kalli, E., Lappa, I., Bouchagier, P., Tarantilis, P. A., \& Skotti, E. (2018). Novel application and industrial exploitation of winery by-products. Bioresources and Bioprocessing, 5 (1), 46. https://doi.org/10.1186/s40643-018-0232-6

Karacabey, E., \& Mazza, G. (2008). Optimization of Solid-Liquid extraction of resveratrol and other phenolic compounds from milled grape canes (Vitis vinifera). Journal of Agricultural and Food Chemistry, 56(15), 6318-6325. https://doi.org/ $10.1021 / \mathrm{jf} 800687 \mathrm{~b}$

Karnopp, A. R., Margraf, T., Maciel, L. G., Santos, J. S., \& Granato, D. (2017). Chemical composition, nutritional and in vitro functional properties of by-products from the Brazilian organic grape juice industry. International Food Research Journal, 24(1), 207-214. 
Karovičová, J., Kohajdová, Z., Minarovičová, L., \& Kuchtová, V. (2015). The chemical composition of grape fibre. Potravinarstvo, 9(1), 53-57. https://doi.org/10.5219/ 428

Kaur, R., Gul, K., \& Singh, A. K. (2016). Nutritional impact of ohmic heating on fruits and vegetables - a review. Cogent Food \& Agriculture, 2(1). https://doi.org/10.1080/ 23311932.2016.1159000

Khan, M. K., Ahmad, K., Hassan, S., Imran, M., Ahmad, N., \& Xu, C. (2018). Effect of novel technologies on polyphenols during food processing. Innovative Food Science Emerging Technologies, 45, 361-381. https://doi.org/10.1016/j.ifset.2017.12.006.

Krishnaswamy, K., Orsat, V., Gariépy, Y., \& Thangavel, K. (2013). Optimization of microwave-assisted extraction of phenolic antioxidants from grape seeds (Vitis vinifera). Food and Bioprocess Technology, 6(2), 441-455. https://doi.org/10.1007/ s11947-012-0800-2

Kwiatkowski, M., Kravchuk, O., Skouroumounis, G. K., \& Taylor, D. K. (2020). Response surface parallel optimization of extraction of total phenolics from separate white and red grape skin mixtures with microwave-assisted and conventional thermal methods. Journal of Cleaner Production. https://doi.org/10.1016/j.jclepro.2019.119563

Liazid, A., Guerrero, R. F., Cantos, E., Palma, M., \& Barroso, C. G. (2011). Microwave assisted extraction of anthocyanins from grape skins. Food Chemistry, 124(3), 1238-1243. https://doi.org/10.1016/j.foodchem.2010.07.053

Li, Y., Skouroumounis, G. K., Elsey, G. M., \& Taylor, D. K. (2011). Microwave-assistance provides very rapid and efficient extraction of grape seed polyphenols. Food Chemistry, 129(2), 570-576. https://doi.org/10.1016/j.foodchem.2011.04.068.

Manna, L., Bugnone, C. A., \& Banchero, M. (2015). Valorization of hazelnut, coffee and grape wastes through supercritical fluid extraction of triglycerides and polyphenols. The Journal of Supercritical Fluids, 104, 204-211. https://doi.org/10.1016/j. supflu.2015.06.012

Maroun, R. G., Rajha, H. N., Vorobiev, E., \& Louka, N. (2017). Emerging technologies for the recovery of valuable compounds from grape processing by-products. In C. M. Galanakis (Ed.), Handbook of grape processing by-products: Sustainable solutions (pp. 155-181). https://doi.org/10.1016/B978-0-12-809870-7.00007-7

Martillanes, S., Rocha-Pimienta, J., \& Delgado- Adámez, J. (2018). Agrifood by-products as a source of phytochemical compounds. Descriptive food science. https://doi.org/ 10.5772/intechopen.79434

Mendívil, M. A., Muñoz, P., Morales, M. P., Juárez, M. C., \& García-Escudero, E. (2013). Chemical characterization of pruned vine shoots from La Rioja (Spain) for obtaining solid bio-fuels. Journal of Renewable and Sustainable Energy, 5(3), 33113. https://doi. org/10.1063/1.4808043

Nagarajan, J., Krishnamurthy, N. P., Nagasundara Ramanan, R., Raghunandan, M. E., Galanakis, C. M., \& Ooi, C. W. (2019). A facile water-induced complexation of lycopene and pectin from pink guava byproduct: Extraction, characterization and kinetic studies. Food Chemistry. https://doi.org/10.1016/j.foodchem.2019.05.135

Namir, M., Siliha, H., \& Ramadan, M. F. (2015). Fiber pectin from tomato pomace: Characteristics, functional properties and application in low-fat beef burger. Journal of Food Measurement and Characterization, 9(3), 305-312. https://doi.org/10.1007/ s11694-015-9236-5

Oiv. (2018). Global economic vitiviniculture data. Organisation Internationale de La Vigne et Du Vin Publication.

Oliveira, D. A., Salvador, A. A., Smânia, A., Smânia, E. F. A., Maraschin, M., \& Ferreira, S. R. S. (2013). Antimicrobial activity and composition profile of grape (Vitis vinifera) pomace extracts obtained by supercritical fluids. Journal of Biotechnology, 164(3), 423-432. https://doi.org/10.1016/j.jbiotec.2012.09.014

O'Shea, N., Arendt, E. K., \& Gallagher, E. (2012). Dietary fibre and phytochemical characteristics of fruit and vegetable by-products and their recent applications as novel ingredients in food products. Innovative Food Science \& Emerging Technologies, 16, 1-10. https://doi.org/10.1016/j.ifset.2012.06.002

Parniakov, O., Barba, F. J., Grimi, N., Lebovka, N., \& Vorobiev, E. (2016). Extraction assisted by pulsed electric energy as a potential tool for green and sustainable recovery of nutritionally valuable compounds from mango peels. Food Chemistry, 192, 842-848. https://doi.org/10.1016/j.foodchem.2015.07.096

Pereira, R. N., Coelho, M. I., Genisheva, Z., Fernandes, J. M., Vicente, A. A., Pintado, M. E., et al. (2020). Using Ohmic Heating effect on grape skins as a pretreatment for anthocyanins extraction. Food and Bioproducts Processing. htt ps://doi.org/10.1016/j.fbp.2020.09.009.

Pereira, R. N., Rodrigues, R. M., Genisheva, Z., Oliveira, H., de Freitas, V., Teixeira, J.a. et al. (2016). Effects of ohmic heating on extraction of food-grade phytochemicals from colored potato. Lebensmittel-Wissenschaft und -Technologie- Food Science and Technology, 74, 493-503. https://doi.org/10.1016/j.lwt.2016.07.074

Pereira, R. N., Teixeira, J. A., \& Vicente, A. A. (2011). Exploring the denaturation of whey proteins upon application of moderate electric fields: A kinetic and thermodynamic study. Journal of Agricultural and Food Chemistry, 59(21), 11589-11597. https://doi.org/10.1021/jf201727s

Peterson, J., Dwyer, J., Adlercreutz, H., Scalbert, A., Jacques, P., \& McCullough, M. L. (2010). Dietary lignans: Physiology and potential for cardiovascular disease risk reduction. Nutrition Reviews, 68(10), 571-603. https://doi.org/10.1111/j.17534887.2010.00319.x

Phan-Thien, K.-Y., Wright, G. C., \& Lee, N. A. (2012). Inductively coupled plasma-mass spectrometry (ICP-MS) and -optical emission spectroscopy (ICP-OES) for determination of essential minerals in closed acid digestates of peanuts (Arachis hypogaea L.). Food Chemistry. https://doi.org/10.1016/j.foodchem.2012.02.095.
Piñeiro, Z., Marrufo-Curtido, A., Vela, C., \& Palma, M. (2017). Microwave-assisted extraction of stilbenes from woody vine material. Food and Bioproducts Processing, 103, 18-26. https://doi.org/10.1016/j.fbp.2017.02.006.

Plaza, M., \& Marina, M. L. (2019). Pressurized hot water extraction of bioactives. In TrAC trends in analytical chemistry. https://doi.org/10.1016/j.trac.2019.03.024

Prozil, S. O., Evtuguin, D. V., \& Lopes, L. P. C. (2012). Chemical composition of grape stalks of Vitis vinifera L. from red grape pomaces. Industrial Crops and Products, 35 (1), 178-184. https://doi.org/10.1016/j.indcrop.2011.06.035

Rajha, H. N., Boussetta, N., Louka, N., Maroun, R. G., \& Vorobiev, E. (2015). Effect of alternative physical pretreatments (pulsed electric field, high voltage electrical discharges and ultrasound) on the dead-end ultrafiltration of vine-shoot extracts. Separation and Purification Technology, 146, 243-251. https://doi.org/10.1016/j. seppur.2015.03.058.

Ribeiro, T. P., de Lima, M. A. C., Alves, R. E., Gonçalves, A. L. de S., \& Souza, A. P. C. (2018). Chemical characterization of winemaking byproducts from grape varieties cultivated in Vale do São Francisco, Brazil. Food Science and Technology. https://doi. org/10.1590/fst.01116

Rocha, C. M. R., Genisheva, Z., Ferreira-Santos, P., Rodrigues, R., Vicente, A. A., Teixeira, J. A., et al. (2018). Electric field-based technologies for valorization of bioresources. Bioresource Technology, 254, 325-339. https://doi.org/10.1016/j. biortech.2018.01.068

Rocha, C. B. da, \& Noreña, C. P. Z. (2020). Microwave-assisted extraction and ultrasound-assisted extraction of bioactive compounds from grape pomace. International Journal of Food Engineering, 16(1-2), 20190191. https://doi.org/10. 1515/ijfe-2019-0191.

Rodrigues, R. M., Martins, A. J., Ramos, O. L., Malcata, F. X., Teixeira, J. A., Vicente, A. A., et al. (2015). Influence of moderate electric fields on gelation of whey protein isolate. Food Hydrocolloids, 43, 329-339. https://doi.org/10.1016/j. foodhyd.2014.06.002

Rojas, M. C., \& Brewer, M. S. (2008). Effect of natural antioxidants on oxidative stability of frozen, vacuum-packaged beef and pork. Journal of Food Quality, 31(2), 173-188. https://doi.org/10.1111/j.1745-4557.2008.00196.x

Sánchez-Gómez, R., Zalacain, A., Alonso, G. L., \& Salinas, M. R. (2014). Vine-Shoot waste aqueous extracts for Re-use in agriculture obtained by different extraction techniques: Phenolic, volatile, and mineral compounds. Journal of Agricultural and Food Chemistry, 62(45), 10861-10872. https://doi.org/10.1021/jf503929v

Sarfarazi, M., Jafari, S. M., Rajabzadeh, G., \& Galanakis, C. M. (2020). Evaluation of microwave-assisted extraction technology for separation of bioactive components of saffron (Crocus sativus L.). Industrial Crops and Products. https://doi.org/10.1016/j. indcrop.2019.111978

Sousa, E. C., DuarteAlexandrino, C., Carioca, J. O. B., Rodrigues, S. P., UchôaThomaz, A. M. A., Rodrigues, L. L., Lima, A., de Ferreira, P. A. T., Morais, S. M. de, Rodrigues, A. L. M., Martins, C. G., \& Silva, J. do N. (2014). Chemical composition and bioactive compounds of grape pomace (Vitis vinifera L.), Benitaka variety, grown in the semiarid region of Northeast Brazil. Food Science and Technology (Campinas), 34(1), 135-142. https://doi.org/10.1590/s0101-20612014000100020

de Souza, R. de C., Machado, B. A. S., Barreto, G. de A., Leal, I. L., Anjos, J. P. dos, \& Umsza-Guez, M. A. (2020). Effect of experimental parameters on the extraction of grape seed oil obtained by low pressure and supercritical fluid extraction. Molecules, 25(7), 1634. https://doi.org/10.3390/molecules25071634

Tahergorabi, R., \& Hosseini, S. V. (2017). Chapter 2 - proteins, peptides, and amino acids A2 - Galanakis, charis M. BT - nutraceutical and functional food components. Academic Press. https://doi.org/10.1016/B978-0-12-805257-0.00002-8.

Teo, C. C., Tan, S. N., Yong, J. W. H., Hew, C. S., \& Ong, E. S. (2010). Pressurized hot water extraction (PHWE). Journal of Chromatography A. https://doi.org/10.1016/j. chroma.2009.12.050

Tseng, A., \& Zhao, Y. (2013). Wine grape pomace as antioxidant dietary fibre for enhancing nutritional value and improving storability of yogurt and salad dressing. Food Chemistry, 138(1), 356-365. https://doi.org/10.1016/j.foodchem.2012.09.148

Urquiaga, I., D’Acuña, S., Pérez, D., Dicenta, S., Echeverría, G., Rigotti, A., et al. (2015). Wine grape pomace flour improves blood pressure, fasting glucose and protein damage in humans: A randomized controlled trial. Biological Research. https://doi org/10.1186/s40659-015-0040-9

Varadharajan, V., Shanmugam, S., \& Ramaswamy, A. (2017). Model generation and process optimization of microwave-assisted aqueous extraction of anthocyanins from grape juice waste. Journal of Food Process Engineering, 40(3). https://doi.org/ 10.1111/jfpe.12486

Vergara-Salinas, José, R., Bulnes, P., Zúñiga, M. C., Pérez-Jiménez, J., Torres, J. L., et al. (2013). Effect of pressurized hot water extraction on antioxidants from grape pomace before and after enological fermentation. Journal of Agricultural and Food Chemistry. https://doi.org/10.1021/jf4010143

Vergara-Salinas, J. R., Vergara, M., Altamirano, C., Gonzalez, Á., \& Pérez-Correa, J. R. (2015). Characterization of pressurized hot water extracts of grape pomace: Chemical and biological antioxidant activity. Food Chemistry. https://doi.org/ 10.1016/j.foodchem.2014.08.094

Yammine, S., Ghidossi, R., \& Mietton-Peuchot, M. (2014). Extraction and purification of phenolic compounds from by-products of the winemaking process. In Wine: Phenolic composition, classification and health benefits.

Zinoviadou, K. G., Galanakis, C. M., Brnčić, M., Grimi, N., Boussetta, N., Mota, M. J., et al. (2015). Fruit juice sonication: Implications on food safety and physicochemical and nutritional properties. Food Research International. https://doi.org/10.1016/j. foodres.2015.05.032 